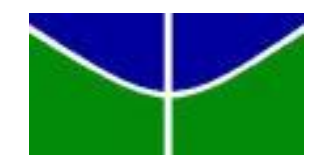

Universidade de Brasília

Faculdade de Direito

LUÍS PAULO BOGLIOLO PIANCASTELLI DE SIQUEIRA

A Relação Entre a Responsabilidade do Estado e do Indivíduo por Crimes Internacionais 
LUÍS PAULO BOGLIOLO PIANCASTELLI DE SIQUEIRA

\section{A RELAÇÃO ENTRE A RESPONSABILIDADE DO ESTADO E DO INDIVÍDUO POR CRIMES INTERNACIONAIS}

Trabalho de Conclusão de Curso apresentado ao Curso de Graduação em Direito da Universidade de Brasília, como requisito parcial à obtenção do título de Bacharel em Direito.

Orientador: Prof. Dr. George Rodrigo Bandeira Galindo 
Why in the world are we here? Surely not to live in pain and fear

John Winston Lennon Instant Karma 


\section{RESUMO}

Nas últimas duas décadas, o fortalecimento do princípio da responsabilidade internacional penal individual consolidou um regime de normas secundárias que coexiste com o regime, mais antigo, da responsabilidade do Estado por atos internacionalmente ilícitos. A relação entre as duas formas de responsabilidade se tornou, assim, uma questão relevante para o direito internacional e para os tribunais internacionais. Este trabalho examina os pontos de contato entre a responsabilidade individual e estatal por crimes internacionais e sugere que a prática recente indica uma relação muito próxima entre os dois regimes. Ele apóia a teoria de Beatrice I. Bonafè, segundo a qual há uma unidade no nível de normas primárias que definem os crimes internacionais e uma dualidade de normas secundárias que estabelecem as condições para atribuição de responsabilidade. Finalmente, o trabalho critica a visão compartimentalizada da responsabilidade internacional que tem sido adotada por tribunais internacionais. A luta pela proteção dos direitos humanos e contra a impunidade deve se atentar ao fato de que tanto Estados como indivíduos cometem crimes internacionais, de modo que ambos devem ser punidos por esses atos.

PALAVRAS-CHAVE: crimes internacionais; responsabilidade internacional; direito internacional penal; genocídio; crimes contra a humanidade; crimes de guerra; agressão. 


\begin{abstract}
In the last two decades, the principle of individual criminal responsibility has consolidated a regime of secondary norms that stands beside the older regime of State responsibility for internationally wrongful acts. The relationship between these two forms of responsibility has thus become a matter of concern for international law and international tribunals. This paper analyses the contact points between State and individual responsibility for international crimes, suggesting that recent practice indicates a very close relationship between the two regimes. It supports the theory proposed by Beatrice I. Bonafè according to which there is a unity at the level of primary norms that describe international crimes and a duality of secondary norms that establish the conditions for attribution of responsibility for international crimes. Finally, it criticizes the compartmentalized approach to individual and State responsibility that has been adopted by international tribunals. The struggle for the protection of human rights and against impunity must take into account that States and individuals commit international crimes and therefore both should be accordingly punished.
\end{abstract}

KEY WORDS: international crimes; international responsibility; international criminal law; genocide; crimes against humanity; war crimes; aggression. 


\section{SUMÁRIO}

Introdução - p. 1

1. Fundamentos da responsabilidade do Estado e do indivíduo por crimes internacionais - p. 6

1.1 A responsabilidade agravada do Estado - p. 6

1.2 A responsabilidade penal do indivíduo - p. 11

2. A Relação entre a Responsabilidade do Estado e do Indivíduo por Crimes Internacionais na Doutrina, nos Artigos da CDI e no Estatuto de Roma - p. 18

2.1 Os Artigos da CDI, o Estatuto de Roma e a Indefinição da Relação - p. 18

2.2 Abordagens Teóricas à Relação entre a Responsabilidade do Indivíduo e do Estado por Crimes Internacionais - p. 19

2.2.1 Um conjunto de regras primárias, dois regimes de regras secundárias - p. 20

2.2.2 Dois conjuntos de regras primárias, dois regimes de regras secundárias -p. 22

3. A Relação entre a Responsabilidade do Estado e do Indivíduo por Crimes Internacionais na Prática Internacional - p. 25

$3.1 \mathrm{O}$ elemento material dos crimes internacionais - p. 25

$3.2 \mathrm{O}$ elemento subjetivo dos crimes internacionais - p. 27

3.3 Excludentes de ilicitude de crimes internacionais - p. 29

3.3.1 Legítima defesa - p. 30

3.4 Crimes Internacionais em espécie - p. 32

3.4.1 Genocídio - p. 32

3.4.2 Crimes contra a humanidade - p. 36

3.4.3 Crimes de Guerra - p. 38

3.4.4 Agressão - p. 39

Conclusão - p. 43

Bibliografia - p. 46 


\section{Introdução}

"Somewhere among men the unconditioned prevails - the capacity to live only together or not at all"

Karl Jaspers ${ }^{1}$

A responsabilidade dos Estados no direito internacional é comumente explicada como o consectário lógico de uma obrigação. ${ }^{2}$ Não seria exagerado afirmar, portanto, que a responsabilidade constitui uma parte essencial do direito internacional. Nas palavras de Alain Pellet, "a responsabilidade é o corolário necessário do direito internacional; ela é também a melhor prova de sua existência e a garantia mais segura de sua efetividade". 3

Sem a responsabilização dos sujeitos que violam o direito internacional, este pouca importância teria como sistema de regulação e estabilização de expectativas na comunidade internacional. ${ }^{4}$ Alguns autores, a exemplo de Roberto Ago, chegam a afirmar que "negar a ideia de uma responsabilidade dos Estados seria negar a própria existência de uma ordem jurídica internacional", 5 ideia que se resume na máxima "pas de responsabilité, pas de droit" (ausente a responsabilidade, ausente o direito).

Se, por um lado, é descomedido utilizar como critério de existência do próprio direito a existência de um sistema de responsabilidade, ${ }^{6}$ por outro, é certo que ubi responsabilitas ibi ius (onde há responsabilidade há direito). Assim, a evolução do direito internacional está intrinsecamente ligada ao desenvolvimento da responsabilidade internacional, por esta constituir, nas palavras de Paul Reuter, "o seu coração, parte essencial daquilo que se pode considerar a constituição da comunidade internacional". 7

\footnotetext{
${ }^{1}$ JASPERS, Karl. The Question of German Guilt. Trad. E. B. Ashton. Nova Iorque: Fordham University Press, 2000, p. 32.

${ }^{2}$ Segundo a célebre afirmação de um famoso árbitro internacional da primeira metade do século XX, Max Huber, "it is an undisputable principle that responsibility is the necessary corollary of rights.." in: CRAWFORD, James. The International Law Commission's Articles on State Responsibility: Introduction, Text and Commentaries. Cambridge: Cambridge University Press, 2002, p. 78.

${ }^{3}$ PELLET, Alain. La responsabilité en droit international: une introduction. [S.I.]: Audiovisual Library of International Law, 2010. Disponível em: http://www.un.org/law/avl/. Acesso em: 18 junho 2010.

${ }^{4}$ Sobre o direito como sistema de regulação e estabilização de expectativas, veja: LUHMANN, Niklas. Sociologia do Direito I. Trad. Gustavo Bayer. Rio de Janeiro: Tempo Brasileiro, 1983, p. 57.

${ }^{5}$ PELLET, Alain. La responsabilité en droit international: une introduction. [S.I.]: Audiovisual Library of International Law, 2010. Disponível em: http://www.un.org/law/avl/. Acesso em: 22 junho 2010.

${ }^{6} \mathrm{O}$ direito brasileiro, como muitas outras ordens jurídicas, reconhece, por exemplo, a existência de obrigações naturais, que, embora jurídicas, não ensejam a responsabilidade de uma pessoa por sua violação. $\mathrm{O}$ mesmo acontece com direitos constitucionais previstos em normas de eficácia limitada, cuja regulação ainda não tenha sido aprovada pelo Legislativo.

${ }^{7}$ REUTER, Paul. Principes du droit international public. Recueil des Cours de l'Académie de Droit International, tomo 103, 1961, p. 586.
} 
Até a primeira metade do século XX, a disciplina se restringia a relações entre Estados ou à proteção de estrangeiros, atrelada ainda a uma visão realista da ordem internacional. A formulação clássica da responsabilidade dos Estados encontra-se no julgamento da Corte Permanente de Justiça Internacional no caso Usina de Chorzów: "toda violação de uma obrigação implica a obrigação de repará-la". ${ }^{8}$

Essa concepção tradicional parte de uma visão civilista, que restringia a responsabilidade ao dever de reparação, além de pressupor um direito internacional exclusivamente interestatal, fundado em uma concepção positivista da soberania. $\mathrm{O}$ dano era condição necessária da atribuição de responsabilidade ao Estado. A ideia de sanções punitivas (penais) estava excluída, pois implicava um ato de comando incompatível com a soberania dos Estados. Esse paradigma começou a erodir com o final da Segunda Guerra Mundial.

A criação da Organização das Nações Unidas (ONU) e o estabelecimento da Comissão de Direito Internacional (CDI) ${ }^{9}$ inauguraram uma nova fase de codificação do direito internacional, sendo a responsabilidade dos Estados um dos principais temas trabalhados pela CDI nas últimas décadas. O resultado deste trabalho foi a aprovação, em 2001, dos Artigos Sobre a Responsabilidade dos Estados por Atos Internacionalmente Ilícitos. ${ }^{10}$

Fruto desse desenvolvimento costumeiro iniciado no pós-guerra, por vezes chancelado pela CDI, o direito internacional caminhou rumo ao rompimento da antiga unidade conceitual da responsabilidade internacional. Esta deixou de ser reservada aos Estados, passando a ser atributo da personalidade jurídica internacional, que hoje abrange, além de Estados, Organizações Internacionais, indivíduos e diversos tipos de atores não-estatais (organizações não-governamentais, empresas multinacionais, movimentos insurrecionais e de libertação, dentre outros). $\mathrm{O}$ dano se tornou, até certo ponto, prescindível ${ }^{11}$ e até mesmo a ilicitude do ato deixou de ser essencial à responsabilidade, como se depreende do trabalho da CDI sobre a responsabilidade internacional por atos não proibidos pelo direito internacional. ${ }^{12}$

\footnotetext{
${ }^{8}$ Corte Permanente de Justiça Internacional. Caso Usina de Chorzów (Alemanha vs. Polônia). 1928. Disponível em: http://www.icj-cij.org/pcij/serie_A/A_17/54_Usine_de_Chorzow_Fond_Arret.pdf. Acesso em: 20 de junho 2010.

${ }^{9}$ Veja Carta da ONU, art. 13(a), e Resolução da Assembléia Geral da ONU 174(II), de 21 novembro 1947.

${ }^{10}$ Comissão de Direito Intenacional. Yearbook of the International Law Commission. 2001, vol. II (Parte Dois). Veja também o anexo à Resolução da Assembléia Geral da ONU 56/83 de 12 dezembro 2001, corrigida pelo documento A/56/49(Vol. I)/Corr.4.

${ }^{11}$ CRAWFORD, James; OLLESON, Simon. The Nature and Forms of International Responsibility. In: EVANS, Malcolm D. International Law. $2^{\text {a }}$ ed. Nova Iorque: Oxford University Press, 2006, p. 465-466.

${ }^{12}$ Confira, sobre o tema, os artigos da CDI sobre a Prevenção de Danos Transfronteiriços por Atividades Perigosas, adotados em 2001. Cf. Official Records of the General Assembly, Fifty-sixth Session, Supplement No. 10 (A/56/10).
} 
No entanto, talvez o mais importante progresso na disciplina tenha sido a irrupção da responsabilidade penal do indivíduo, que fulminou a unidade clássica da responsabilidade internacional. $\mathrm{O}$ estabelecimento dos Tribunais de Nuremberg e de Tóquio ${ }^{13}$ concretizou a ideia de que indivíduos devem ser punidos por violações de normas internacionais. ${ }^{14}$ Consolidava-se, assim, o direito internacional penal, o qual, após Nuremberg e Tóquio, permaneceu em hibernação até o fim da Guerra Fria, quando ressurge com a criação de novos tribunais internacionais pela ONU.

A partir da década de noventa, há o ressurgimento e o rápido desenvolvimento do direito internacional penal, tendo por consequência a consolidação de um sistema de responsabilização individual por crimes internacionais que se desenvolve paralelamente ao sistema, mais antigo, de responsabilidade dos Estados.

Esta monografia pretende demonstrar as consequências da expansão da responsabilidade individual no campo específico da responsabilidade dos Estados, tendo em foco o fortalecimento da proteção internacional dos direitos humanos. Para tanto, serão analisadas as relações entre as duas formas de responsabilidade e explorados os possíveis pontos de contato entre a responsabilidade do indivíduo e a dos Estados por crimes internacionais.

A escolha de restringir o assunto desta monografia à responsabilidade por crimes internacionais justifica-se por três razões. A primeira refere-se ao fato de que a responsabilidade do indivíduo no direito internacional é quase exclusivamente penal. Em verdade, não há, a princípio, óbices nessa ordem jurídica para que se reconheça uma responsabilidade de caráter civil que possa ser atribuída diretamente ao indivíduo. ${ }^{15}$ Não obstante, a prática atual do direito internacional ainda é incerta quanto ao tema. Desse modo, a restrição da análise à responsabilidade individual penal mostra-se mais frutífera para os propósitos aqui visados, porquanto ela já está consolidada na prática de diversos tribunais internacionais, mistos (ou híbridos) e nacionais.

A segunda razão dessa delimitação é o fato de que, atualmente, a responsabilidade dos Estados pode existir na forma simples ou na forma agravada, sendo a última decorrente de uma violação grave de uma obrigação estabelecida por uma norma peremptória (ius cogens).

\footnotetext{
${ }^{13}$ Veja a Carta de Londres do Tribunal Militar Internacional em Nuremberg, de 8 agosto 1945, e o Tribunal Internacional Militar para o Extremo Oriente (Tribunal de Tóquio), criado por Ordem do General MacArthur de 19 janeiro 1946.

${ }^{14}$ Julgamento dos Principais Criminosos da Guerra. Procedimentos do Tribunal Militar Internacional situado em Nuremberg. Parte 22, parágrafo 447.

${ }^{15}$ SCOTT, Craig. Translating torture into transnational tort: conceptual divides in the debate on corporate accountability for human rights harms. In: SCOTT, Craig (ed). Torture as tort: Comparative perspectives on the development of transnational human rights litigation. Oxford: Hart, 2001, p. 45.
} 
${ }^{16}$ A caracterização da forma agravada de responsabilidade dos Estados oferece certos pontos de contato com a responsabilidade individual que não existem na forma simples de responsabilidade, como a determinação, em alguns casos, do que seria uma violação "grave" ou "sistemática". Embora haja possíveis exceções, ${ }^{17}$ na maioria dos casos em que o direito internacional prevê a responsabilidade penal individual, a responsabilidade do Estado, quando existir, será reconhecida na forma agravada.

Finalmente, justifica-se a restrição aos crimes internacionais por razões práticas, como as limitações ao tamanho do trabalho e o interesse em explorar as consequências das violações mais graves de direitos humanos, deixando de lado casos de menor relevância, que não chegam a ser qualificados como crimes internacionais. Além disso, o exame das relações entre a responsabilidade individual e dos Estados por crimes internacionais permite analisar as relações entre tribunais internacionais que recentemente têm enfrentado questões semelhantes ao julgar Estados e indivíduos ${ }^{18}$.

Cabe esclarecer, aqui, o sentido da expressão "crimes internacionais". O termo será utilizado para indicar as mais sérias violações de normas costumeiras de direito internacional, que implicam tanto a responsabilidade do indivíduo como a do Estado ${ }^{19}$. A ligação do termo apenas aos crimes reconhecidos no direito costumeiro tem a finalidade de excluir a apreciação de condutas criminosas baseadas em tratados específicos e de menor repercussão na prática internacional, que reconhece os assim chamados "core crimes" - genocídio, crimes contra a humanidade, crimes de guerra e agressão.

$\mathrm{Na}$ primeira parte da monografia serão delineados os fundamentos dos dois tipos de responsabilidade internacional. Parte-se do pressuposto de que, ao menos de um ponto de vista conceitual, não se deve negar o fato de que Estados podem perpetrar crimes. ${ }^{20}$ Especial

\footnotetext{
${ }^{16}$ Art. 40 dos Artigos da CDI Sobre a Responsabilidade dos Estados por Atos Internacionalmente Ilícitos:

1. Este capítulo se aplica à responsabilidade internacional decorrente de uma violação grave por um Estado de uma obrigação provinda de uma norma peremptória do direito internacional costumeiro.

2. Uma violação de tal obrigação é grave se envolver a falha grosseira ou sistemática do Estado responsável por cumprir a obrigação.

${ }^{17}$ Por exemplo, no caso de crimes de guerra cometidos de forma isolada, como a execução sumária por um soldado de um combatente inimigo que tenha se rendido.

${ }^{18}$ Este é o caso da questão da atribuição da conduta de um grupo de indivíduos particulares a um Estado. Enquanto a Corte Internacional de Justiça defende o teste do "controle efetivo" do Estado sobre as ações dos indivíduos, com base nos precedentes do Caso Nicarágua vs. Estados Unidos e do Caso do Genocídio (Bósnia vs. Sérvia e Montenegro), o Tribunal Penal Internacional para a Ex-Iugoslávia utiliza o teste do "controle geral", que requer um vínculo mais tênue entre o Estado e a conduta dos particulares. Sobre o assunto: CASSESE, Antonio. The Nicaragua and Tadic Tests Revisited in Light of the ICJ Judgement on Genocide in Bosnia. European Journal of International Law, Vol.18, No.4, 2007.

${ }^{19}$ BONAFE, Beatrice I. The Relationship Between State and Individual Responsibility for International Crimes. Leiden: Martinus Nijhoff Publishers, 2009, p. 11.

${ }^{20}$ PELLET, Alain. Can a State Commit a Crime? Definitely, Yes! European Journal of International Law, Vol. 10, No. 2, 1999, p. 425-434. Veja também: CANÇADO TRINDADE, Antônio Augusto. Complementarity
} 
atenção será dada aos Artigos da CDI Sobre a Responsabilidade dos Estados por Atos Internacionalmente Ilícitos. Por outro lado, algumas linhas serão dedicadas ao desenvolvimento do direito internacional penal desde os anos noventa, com a criação de diversos tribunais internacionais e mistos encarregados de punir indivíduos por violações do direito internacional. Serão descritos os crimes hoje sancionados pelo direito internacional costumeiro e suas peculiaridades.

A segunda parte do trabalho consiste em apresentar as teorias que visam a explicar a relação entre a responsabilidade do indivíduo e a do Estado por crimes internacionais. As duas principais correntes apresentadas emanam dos trabalhos de Beatrice I. Bonafè e de Antonio Cassese. A primeira defende que as normas primárias que definem os crimes internacionais são as mesmas para Estados e indivíduos, havendo uma diferença apenas no nível das normas secundárias, que estabelecem as condições específicas de responsabilização dos sujeitos do direito internacional. Já Cassese sustenta uma dissociação em dois níveis, no das normas primárias e no das normas secundárias. Para ele, os crimes individuais não coincidem e independem dos atos ilícitos dos Estados.

Finalmente, a última parte tratará de contextualizar a relação entre a responsabilidade do indivíduo e do Estado por crimes internacionais, demonstrando como a prática internacional tem modulado essa relação. Serão analisados os elementos constitutivos dos crimes internacionais e explorado o modo pelo qual cada um deles demonstra uma aproximação ou um distanciamento entre a responsabilidade individual e a estatal. Ademais, a parte final do trabalho abordará a interação entre os dois regimes de responsabilidade com relação a cada espécie de crime internacional, a fim de realçar as peculiaridades específicas a cada tipo de violação.

Será feita uma crítica à forma compartimentalizada como os tribunais internacionais têm enfrentado o tema. ${ }^{21}$

\footnotetext{
between State responsibility and individual responsibility for grave violations of human rights: the crime of State revisited. In: RAGAZZI, Maurizio (ed). International Responsibility Today: Essays in Memory of Oscar Schachter. Leiden: Martinus Nijhoff Publishers, 2005, p. 253-269. Vale ressaltar, contudo, que, malgrado possam os Estados cometer crimes, não há, de lege lata, um regime de responsabilidade criminal para os Estados. Com efeito, como explicou o antigo Relator Especial Roberto Ago, a responsabilidade internacional não é nem civil, nem penal, mas internacional. Nesse sentido: CRAWFORD, James. The International Law Commission's Articles on State Responsibility: Introduction, Text and Commentaries. Cambridge: Cambridge University Press, 2002, p. 19.

${ }^{21}$ CANÇADO TRINDADE, Antônio Augusto. Opinião exposta em Audiência Pública realizada no dia 18 de dezembro de 2008 no Senado Brasileiro.
} 


\section{Capítulo 1. Fundamentos da responsabilidade do Estado e do indivíduo por crimes internacionais}

\subsection{A responsabilidade agravada do Estado}

O Estado, sendo um sujeito do direito internacional, é um centro de imputação de condutas. Se é certo que condutas podem ser atribuídas diretamente ao Estado, ainda que, na prática, toda conduta parta de um ser humano, é também correto afirmar que ao Estado podem ser imputadas condutas criminosas - societas delinquere potest. ${ }^{22} \mathrm{Em}$ outras palavras, em termos conceituais é perfeitamente possível que um Estado cometa um crime. Nas palavras de James Crawford:

A ausência de um sistema adequado de responsabilidade penal do Estado não é um problema de conceito, mas de organização, de estrutura e da falta de instituições apropriadas. Não há nada inerente ao Estado que exclua sua sujeição a sanções penais. ${ }^{23}$

A ideia de que Estados podem perpetrar crimes foi introduzida no Projeto de Artigos da CDI Sobre a Responsabilidade dos Estados por Atos Internacionalmente Ilícitos pelo Relator Especial Roberto Ago, no controverso e posteriormente excluído artigo 19, que enunciava:

Um ato internacionalmente ilícito que resulta da violação por um Estado de uma obrigação internacional tão essencial à proteção dos interesses fundamentais da comunidade internacional que sua transgressão é reconhecida como um crime por aquela comunidade como um todo constitui um crime internacional. ${ }^{24}$

Este artigo provocou enorme polêmica quanto à utilização do termo "crime", suas implicações e a eventual confusão com a responsabilidade individual no direito internacional. Além disso, a admissão de um regime penal de responsabilidade dos Estados implicaria consequências que muitos Estados não estavam dispostos a aceitar e que não eram previstas

\footnotetext{
${ }^{22}$ CANÇADO TRINDADE, Antônio Augusto. Complementarity between State responsibility and individual responsibility for grave violations of human rights: the crime of State revisited. In: RAGAZZI, Maurizio (ed). International Responsibility Today: Essays in Memory of Oscar Schachter. Leiden: Martinus Nijhoff Publishers, 2005, p. 253-269.

${ }^{23}$ CRAWFORD, James. The International Law Commission's Articles on State Responsibility: Introduction, Text and Commentaries. Cambridge: Cambridge University Press, 2002, p. 19.

${ }^{24}$ Comissão de Direito Internacional. Draft Articles on State Responsibility with commentaries thereto adopted by the International Law Commission on First Reading, 1997. Disponível em: http://untreaty.un.org/ilc/texts/instruments/english/commentaries/9_6_1996.pdf Acesso em 24 junho 2010.
} 
no projeto da CDI: a definição dos crimes internacionais, segundo o princípio nullum crimen sine lege; a criação de um procedimento de investigação de crimes em nome da comunidade internacional; um sistema de devido processo legal para o julgamento dos crimes; a possibilidade de aplicação de sanções apropriadas após a constatação de que um crime foi cometido; e um meio pelo qual o Estado criminoso pudesse purgar sua culpa. ${ }^{25}$

Em razão das amplas divergências e do potencial destrutivo da ideia de crimes para o projeto da CDI como um todo, ${ }^{26}$ o último Relator Especial, James Crawford, houve por bem excluir o termo do projeto. No entanto, foi constatado que não havia dificuldades em se reconhecer que algumas obrigações no direito internacional são devidas à comunidade internacional como um todo e que graves violações dessas obrigações poderiam levar a consequências especiais.

Assim, os artigos adotados pela Assembléia Geral da ONU em 2001 incluem um Capítulo (III) na Parte II do Projeto que dispõe sobre "graves violações de obrigações decorrentes de normas peremptórias do direito internacional costumeiro”. Excluído o termo "crime" e a possibilidade de eventuais sanções de caráter penal, como as punitive damages, evitou-se a antiga distinção entre crimes e delitos proposta por Roberto Ago. Por isso, não se pode afirmar, de lege lata, que há uma responsabilidade penal dos Estados no direito internacional. Contudo, não seria exagerado afirmar que a ideia subjacente - de que Estados, como sujeitos do direito internacional, podem cometer crimes - permanece intacta nos artigos da CDI. ${ }^{27}$ Tanto que, para os fins deste trabalho, a definição de "crimes internacionais" utilizada na introdução em muito se assemelha com a definição contida no artigo 40 do projeto da CDI:

Art. 40 - Aplicação deste capítulo

1. Este capítulo se aplica à responsabilidade internacional decorrente de uma violação grave por um Estado de uma obrigação provinda de uma norma peremptória do direito internacional costumeiro.

\footnotetext{
${ }^{25}$ CRAWFORD, James. The International Law Commission's Articles on State Responsibility: Introduction, Text and Commentaries. Cambridge: Cambridge University Press, 2002, p. 18.

${ }^{26}$ Id. p. 20.

${ }^{27}$ Nas palavras de Alain Pellet, Mathias Forteau e Patrick Daillier, os artigos da CDI "perenizaram" a noção de crimes internacionais sem, contudo, dar-lhes esse nome. Os atualizadores do prestigiado manual de Ngyuen Quoc Dinh defendem que "entre um genocídio e a simples violação de um acordo comercial bilateral há uma diferença não apenas de grau, mas de natureza: mesmo ilícita, a segunda violação interessa apenas aos dois Estados partes do acordo, ao contrário do genocídio, que repugna a consciência de toda a humanidade e ameaça os próprios fundamentos da frágil comunidade internacional”. In: QUOC DIN, Nguyen; DAILLIER, Patrick; FORTEAU, Mathias; e PELLET, Alain. Droit International Public. LGDJ. $8^{\text {a }}$ Ed. Paris, 2009.
} 
2. Uma violação de tal obrigação é grave se envolver a falha grosseira ou sistemática do Estado responsável por cumprir a obrigação. ${ }^{28}$

A noção de responsabilidade agravada está diretamente vinculada à de normas peremptórias (ius cogens), por um lado, e à de obrigações erga omnes, por outro. Com efeito, a CDI entende que, malgrado exista uma diferença na ênfase de cada uma, há uma considerável sobreposição entre normas ius cogens e obrigações devidas à comunidade internacional como um todo. ${ }^{29}$ Pode se afirmar, para fins didáticos, que toda norma peremptória é também uma obrigação erga omnes, mas que nem toda obrigação erga omnes é uma norma ius cogens. Talvez a teoria que melhor explique a relação entre esses conceitos e o de crimes internacionais seja a dos círculos concêntricos, de Giorgio Gaja. ${ }^{30}$ Segundo essa teoria, o círculo maior seria o das obrigações erga omnes, dentro do qual estaria o círculo das normas ius cogens, que englobaria o círculo dos crimes internacionais. ${ }^{31}$

Além de a obrigação violada ter que emanar de uma norma peremptória, outro quesito necessário para o desencadeamento da responsabilidade agravada é o da intensidade da violação, que deve ser de natureza grave. A palavra grave (serious no original em inglês) significa que a violação deve atingir certa magnitude. ${ }^{32}$ Os parâmetros utilizados para se aferir a referida magnitude são a sistematicidade ou a flagrância da violação. O primeiro se refere ao modo organizado e deliberado de uma transgressão, o segundo à sua intensidade ou ao seu caráter flagrante. ${ }^{33}$

Partindo dos pressupostos acima e da definição de crimes internacionais aqui esposada (as mais sérias violações de normas costumeiras de direito internacional, que implicam tanto a responsabilidade do indivíduo como a do Estado), conclui-se que a perpetração de um crime internacional por um Estado implica sua responsabilidade agravada. O mesmo, contudo, não pode ser dito quanto a todos os atos que importem a responsabilidade penal do indivíduo.

\footnotetext{
${ }^{28}$ Art. 40 dos Artigos da CDI Sobre a Responsabilidade dos Estados por Atos Internacionalmente Ilícitos (tradução do autor).

${ }^{29}$ Id. p. 244.

${ }^{30}$ GALINDO, George Rodrigo Bandeira. O Crime Compensa? Acerca da viabilidade da noção de crimes internacionais no Direito Internacional. Revista de Informação Legislativa. Brasília, a. 37, No. 147, jul./set. 2000 , p. 219.

${ }^{31}$ GAJA, Giorgio. Obligations erga omnes, international crimes and jus cogens: a tentative analysis of three related concepts. In: WEILER, Joseph H. H.; CASSESE, Antonio; SPINEDI, Marina (eds.). International Crimes of State: a critical analysis of the ILC's draft article 19 on State responsibility. Berlin, Nova Iorque: de Gruyter, 1988.

${ }^{32}$ Como explicam Alain Pellet, Mathias Forteau e Patrick Daillier, toda violação de uma norma ius cogens é grave em um plano moral ou político. Entretanto, no plano jurídico há violações - como genocídio e agressão que automaticamente se qualificam como graves, enquanto outras - como a tortura -, embora pertençam ao domínio do ius cogens, nem sempre serão consideradas graves no sentido do art. 40 do projeto da CDI. Neste sentido, confira o caso Selmouni, da Corte Européia de Direitos Humanos, julgamento 28 julho 1999.

${ }^{33}$ CRAWFORD, James. The International Law Commission's Articles on State Responsibility: Introduction, Text and Commentaries. Cambridge: Cambridge University Press, 2002, p. 247.
} 
Com efeito, há casos em que o indivíduo pode cometer um crime internacional sem que isso implique a responsabilidade agravada do Estado - por exemplo, alguns crimes de guerra cometidos por um soldado de forma isolada e não-sistemática.

$\mathrm{O}$ artigo 41 do projeto da CDI prevê duas consequências principais para a responsabilidade agravada dos Estados: 1) a obrigação de cooperação entre os Estados para por fim, por meios legais, a uma violação grave no sentido do artigo 40; e 2) a obrigação de não reconhecer como legal a situação criada por uma violação grave no sentido do artigo 40 e de não ajudar ou auxiliar na manutenção dessa situação. Esses efeitos são adicionais às consequências habituais decorrentes de um ato internacionalmente ilícito. Desse modo, a responsabilidade agravada dos Estados foi concebida como consequências suplementares às regras secundárias ordinárias, e não como um novo conjunto de regras secundárias. Essa abordagem ficou conhecida como "délit plus", ${ }^{34}$ pois ao invés de traçar uma distinção clara entre crimes e delitos, como outrora fazia o projeto da CDI, ela acrescenta às consequências ordinárias decorrentes de atos ilícitos comuns (delitos) certos efeitos, que não chegam a ter um caráter penal, mas que emanam de violações graves de normas ius cogens.

Segundo André Nollkaemper, a responsabilidade agravada dos Estados por crimes internacionais possui duas funções: a reparatória e a sistêmica. ${ }^{35}$ A primeira tem o objetivo de compensar o dano causado às vítimas, aproximando-se da responsabilidade civil por atos criminosos existente em diversas ordens jurídicas nacionais. ${ }^{36}$ Já a segunda função é exclusiva da responsabilidade agravada, tendo por objetivo coibir violações do direito internacional que são parte de uma política sistemática de um Estado. Com efeito, alguns crimes internacionais, ainda que possam na teoria ser cometidos por atores não-estatais, são quase sempre dependentes de um aparelho estatal que permite sua execução. Este é o caso dos crimes contra a humanidade, genocídio, agressão e de alguns crimes de guerra. ${ }^{37}$ Como bem expôs Hannah Arendt, “crimes desse tipo foram e só podem ser cometidos por um Estado criminoso". 38

\footnotetext{
${ }^{34}$ BONAFÈ, Beatrice I. The Relationship Between State and Individual Responsibility for International Crimes. Leiden: Martinus Nijhoff Publishers, 2009, p. 11.

${ }^{35}$ NOLLKAEMPER, André. Concurrence between individual responsibility and state responsibility in international law. International and Comparative Law Quarterly. Vol.52, julho 2003, p. 622.

${ }^{36}$ Veja, no direito brasileiro, o art. 63 e seguintes do Código de Processo Penal (Decreto-Lei 3.689/1941).

${ }^{37} \mathrm{O}$ Estatuto de Roma, embora dirigido a condutas individuais, estabelece alguns crimes de guerra que dependem de um aparelho estatal, ou, ao menos, de uma coletividade para serem executados. Exemplos: pilhar uma cidade - art. 8(2)(b)(xvi); privar um prisioneiro de guerra ou uma pessoa protegida do direito ao devido processo legal - art. 8(2)(a)(vi); deportação, transferência ou confinamento ilegal de pessoas protegidas - art. $8(2)(a)($ vii).

${ }^{38}$ ARENDT, Hannah. Eichmann in Jerusalem. A report on the banality of evil. Nova Iorque: Viking Press, 1963 , p. 240.
} 
Nesses casos, destaca-se a obrigação dos Estados de cooperarem entre si para por um fim, por meios legais, à violação. As consequências ligadas à função sistêmica da responsabilidade agravada ainda não podem ser consideradas normas de direito costumeiro, pois a prática dos Estados ainda é muito ambígua e seletiva. Há casos em que a comunidade internacional efetivamente coopera para por fim a um crime internacional, como no caso da Primeira Guerra do Golfo. ${ }^{39}$ Em outras ocasiões, porém, crimes bárbaros como os perpetrados pelo Khmer Rouge, ${ }^{40}$ no Camboja, são ignorados pela comunidade de Estados. Por conseguinte, se não é exato afirmar que a função sistêmica da responsabilidade agravada faz parte do direito costumeiro, é justo ao menos colocá-la na zona cinzenta entre a lege lata e a lege ferenda. ${ }^{41}$

Conquanto a responsabilidade agravada dos Estados ainda esteja em uma fase pouco desenvolvida, é indispensável entender sua importância na repressão dos crimes internacionais. Não se deve permitir que o estabelecimento da responsabilidade individual ofusque a relevância da responsabilidade dos Estados, visto que "seria estranho considerar que o presidente de um Estado deva ser preso por muitos anos, enquanto se deixam no lugar as estruturas que tornaram possíveis e facilitaram seus atos criminosos". ${ }^{42}$ Nesse sentido, é também de se refutar a ideia de que a responsabilidade dos Estados equivale à determinação da culpa coletiva de um povo. Michael Walzer explica que "a distribuição de custos não é a distribuição de culpa" ${ }^{43}$ e que, apesar de nem todos os cidadãos serem os autores de todas as políticas estatais, eles podem, ainda assim, responder por elas. Esse ato de compartilhar os encargos da responsabilidade constitui parte essencial do processo de superação e de dissuasão de crimes internacionais. ${ }^{44} \mathrm{~A}$ responsabilidade do indivíduo, enquanto necessária,

\footnotetext{
${ }^{39}$ Ver Resolução 678 do Conselho de Segurança da ONU, de 29 novembro 1990.

${ }^{40}$ Com efeito, o Khmer Rouge continuou a ocupar a cadeira do Camboja na ONU após a invasão vietnamita e apesar das atrocidades cometidas entre 1975 e 1979, que resultaram na morte de mais de dois milhões de pessoas. Apenas em anos recentes as Câmaras Extraordinárias para o Camboja, uma espécie de tribunal misto criado por meio de um acordo entre o governo e a ONU, saíram do papel e iniciaram processos contra os líderes ainda vivos do Khmer Rouge. Sobre o assunto, confira: LINTON, Suzannah. New Approaches to International Justice in Cambodia and East Timor. International Red Cross Review. Vol 84, No. 845, March 2002, PP. 93119. LINTON, Suzannah. Cambodia, East Timor and Sierra Leone: Experiments in International Justice. Criminal Law Forum, No. 12, 2001, pp. 185-246.

${ }^{41}$ A Corte Internacional de Justiça, na Opinião Consultiva sobre as consequências legais da construção do muro no território palestino ocupado, estabeleceu consequências especiais para Israel e para a comunidade internacional. Com efeito, a CIJ asseverou que "todos os Estados têm as obrigações de não reconhecer como lícita a situação ilegal resultante da construção do muro e de não ajudar ou assistir na manutenção da situação criada por tal construção". Cf. Corte Internacional de Justiça, Legal Consequences of the Construction of a Wall in the Occupied Palestinian Territory, Opinião Consultiva de 9 de julho 2004, parágrafo 163.

${ }_{42}$ NOLLKAEMPER, André. Concurrence between individual responsibility and state responsibility in international law. International and Comparative Law Quarterly. Vol.52, julho 2003, p. 625.

${ }^{43}$ WALZER, Michael. Just and unjust wars. Nova Iorque: Basic Books, 1977, p. 297.

${ }^{44}$ FRANCK, Thomas. Individual criminal liability and collective civil responsibility: do they reinforce or contradict one another?. Washington University Global Studies Law Review. Vol. 6:567, 2007, p. 571.
} 
não é, por si só, suficiente para coibir a reprodução de crimes internacionais - é imperioso atribuir responsabilidade também ao Estado, para que ele não sirva mais de instrumento para a prática de atrocidades.

\subsection{A responsabilidade penal do indivíduo}

A punição de indivíduos por transgressões de normas internacionais tornou-se uma realidade após a Segunda Guerra Mundial e a instauração dos Tribunais de Nuremberg e de Tóquio. Apesar das falhas e insuficiências desses dois tribunais - criticados por promoverem uma justiça dos vencedores - eles foram fundamentais para o estabelecimento do princípio da responsabilidade penal do indivíduo no direito internacional. Talvez a frase mais marcante e certamente a mais citada do julgamento dos grandes criminosos de guerra em Nuremberg consolida esse princípio: "crimes contra o direito internacional são cometidos por homens, não por entidades abstratas, e somente punindo os indivíduos que cometem tais crimes podem-se fazer cumprir os dispositivos do direito internacional". 45

Após os grandes julgamentos que marcaram o pós-guerra, o direito internacional penal entrou em um longo período de hibernação. Isso se deve, sobretudo, aos entraves políticos que a guerra fria impunha a seu desenvolvimento. Nos anos noventa, superados os obstáculos políticos e ideológicos que travavam o funcionamento do Conselho de Segurança da Organização das Nações Unidas (CSONU), o direito internacional penal desperta de seu longo sopor com a criação dos tribunais ad hoc para a Ex-Iugoslávia e para Ruanda. ${ }^{46} \mathrm{O}$ trabalho desses tribunais é fundamental para o desenvolvimento da disciplina, proporcionando sua evolução pela via jurisprudencial, meio pelo qual essa matéria ainda rudimentar pode avançar e dar consistência a suas normas.

Os tribunais ad hoc foram criados por resoluções do CSNU e são integrados por juízes e procuradores internacionais. Ficam situados fora dos Estados onde ocorreram os crimes

\footnotetext{
${ }^{45}$ No original: "crimes against international law are committed by men, not by abstract entities, and only by punishing individuals who commit such crimes can the provisions of international law be enforced". Julgamento dos Principais Criminosos da Guerra. Procedimentos do Tribunal Militar Internacional situado em Nuremberg. Parte 22, parágrafo 447. Esta frase não deve ser entendida no sentido de que a responsabilidade dos Estados deve ceder espaço à responsabilidade dos indivíduos. Ela deve ser compreendida em seu contexto histórico, em uma época em que os indivíduos gozavam de impunidade por crimes internacionais devido a uma visão positivista do direito internacional, que reconhecia apenas os Estados como seus sujeitos. Assim, não é correto interpretar esta máxima de Nuremberg no sentido de se excluir a importância da responsabilidade dos Estados, que é complementar à dos indivíduos e essencial para a repressão às graves violações do direito internacional.

${ }^{46}$ Ver, respectivamente, as Resoluções do Conselho de Segurança do ONU 827, de 25 maio 1993, e 955, de 8 novembro 1994.
} 
investigados e são custeados pela ONU. Essas características geraram diversas críticas a esse modelo de justiça internacional, dentre as quais se destacam os enormes custos e a ineficiência dos tribunais ad hoc. ${ }^{47}$ Em resposta a essas críticas, ainda na década de noventa surge a segunda geração de instituições de justiça internacional, materializada no estabelecimento de tribunais mistos ou híbridos (também chamados de internacionalizados), normalmente criados por acordos entre Estados e a ONU, compostos por juízes e procuradores nacionais e internacionais e em regra localizados no país onde os crimes foram praticados. Exemplos desses tribunais são encontrados em Serra Leoa, Camboja, Kosovo e Timor Leste. ${ }^{48}$

O grande passo rumo à consolidação da justiça penal internacional se deu, porém, com o Estatuto de Roma de 1998, que criou o Tribunal Penal Internacional (TPI). ${ }^{49}$ Esta corte, ao contrário das que a precederam, é uma instituição permanente e com pretensões universais visa a ser um verdadeiro tribunal mundial, malgrado a resistência ainda recalcitrante de algumas potências como os EUA, a Rússia, a China e Israel. O Estatuto de Roma contém os fundamentos primordiais de um sistema de direito internacional penal, sendo de grande relevância para a consolidação do princípio da responsabilidade individual penal no direito internacional, que está cristalizado em seu artigo 25: "De acordo com o presente Estatuto, o Tribunal será competente para julgar as pessoas naturais".

A responsabilidade penal internacional do indivíduo surge do cometimento de um crime. Os crimes internacionais são compostos por dois elementos: i) a conduta (elemento objetivo ou actus reus), consistente em um ato ou uma omissão contrária a uma regra que impõe uma conduta específica; e ii) o componente psicológico (elemento subjetivo ou mens rea), que determina a culpabilidade pelo ato. ${ }^{50} \mathrm{O}$ que distingue os crimes internacionais dos crimes comuns encontrados nos direitos pátrios é o "contexto de violência organizada de tais crimes" 51 e o fato de que são punidos em nome da comunidade internacional como um todo. ${ }^{52}$ Essas características afastam, por exemplo, a noção de que a pirataria, tida como o mais antigo crime internacional, o seja no sentido técnico e contemporâneo da palavra. ${ }^{53}$

\footnotetext{
${ }^{47}$ LINTON, Suzannah. New approaches to international justice in Cambodia and East Timor. International Review of the Red Cross, Vol. 84, No. 845, março 2002, p. 113.

${ }^{48}$ Special Court for Sierra Leone, estabelecida em 2002; Extraordinary Chambers in the Courts of Cambodia, estabelecidos em 2006; Special Panels of the Dili District Court, estabelecidos em 2000; e Regulation 64 Panels in the Courts of Kosovo, estabelecidos em 2000.

${ }^{49}$ Estatuto de Roma do Tribunal Penal Internacional, entrou em vigência em 1 julho 2002.

${ }^{50}$ CASSESE, Antonio. International Criminal Law. $2^{\mathrm{a}}$ ed. Oxford: Oxford University Press, 2008, p. 53.

${ }^{51}$ WERLE, Gerhard. Principles of International Criminal Law. Haia: Asser Press, 2005, p. 94-95.

${ }^{52}$ Veja, por exemplo, o conhecido caso: Eichmann, Corte Suprema de Israel, 29 maio 1962. No julgamento da Suprema Corte de Israel, foi enfatizado que os então chamados "crimes contra o povo judeu" eram um tipo particular de crimes contra a humanidade. Ademais, ao afastar o argumento de que os atos praticados por
} 
Dadas as características peculiares dos crimes internacionais acima mencionadas, é de se notar que são poucas as categorias que se encaixam nesse perfil, sobretudo do ponto de vista do direito costumeiro. Com efeito, a diversidade de condutas tipificadas no direito internacional penal geral se resume às seguintes categorias: crimes de guerra, crimes contra a humanidade, genocídio, agressão e tortura. Alguns acadêmicos, a exemplo de Antonio Cassese, acrescentam o terrorismo à lista. ${ }^{54}$ No entanto, deixaremos de lado, neste artigo, a questão do terrorismo, porquanto ainda pairam muitas divergências a respeito da existência de tal crime no direito internacional.

Os crimes de guerra são violações graves de normas costumeiras ou de tratados pertencentes ao direito internacional humanitário (DIH). ${ }^{55}$ Assim, eles só existem em um contexto de conflito armado, seja internacional ou interno (guerra civil). Hoje já não se discute mais a existência de crimes de guerra em conflitos internos, o que vai ao encontro da tendência do direito internacional humanitário de igualar a regulação de conflitos internos à de conflitos internacionais. ${ }^{56}$ No julgamento do caso Tadić, o Tribunal Penal Internacional para a Ex- Iugoslávia (TPIEI) afirmou que os crimes de guerra consistem em: i) uma grave violação (ou seja, uma infração de certa magnitude); ii) de uma regra costumeira ou contida em um tratado; iii) que prevê a responsabilidade penal do indivíduo (tipicidade). ${ }^{57}$

Já os crimes contra a humanidade compreendem uma grande diversidade de condutas, muitas vezes coincidentes com as dos crimes de guerra, que se distinguem pelos seguintes traços: i) são ofensas particularmente execráveis, pois constituem um ataque brutal à dignidade humana; ii) fazem parte de uma prática sistemática ou generalizada de abusos que é objeto de uma política estatal, ou é tolerada ou aquiescida por um Estado; e iii) são punidos independentemente de serem praticados em tempos de guerra ou de paz. Cassese observa que, enquanto os crimes de guerra estão vastamente ligados ao DIH, os crimes contra a humanidade estão em grande medida baseados no direito internacional dos direitos humanos.

Eichmann seriam atos de Estado e, portanto, mereciam imunidade, a Suprema Corte afirmou que o cometimento de crimes internacionais é completamente fora das competências soberanas de um Estado e que aqueles que participam em tais atos não podem se esconder atrás de um suposto caráter oficial de suas ações.

${ }^{53}$ CASSESE, Antonio. International Criminal Law. $2^{\mathrm{a}}$ ed. Oxford: Oxford University Press, 2008, p. 12. Veja também: SCHABAS, William. Piracy, the Crime of Crimes? 2 novembro 2009. Disponível em: http://humanrightsdoctorate.blogspot.com/2009/11/piracy-crime-of-crimes.html . Acesso em: 22 junho 2010.

${ }^{54}$ CASSESE, Antonio. International Criminal Law. $2^{\mathrm{a}}$ ed. Oxford: Oxford University Press, 2008, p. 162-183.

${ }^{55}$ Id. Ibid., p. 81.

${ }^{56}$ Antonio Cassese afirma que o art. $8^{\circ}$ do Estatuto de Roma é retrógrado ao fazer uma distinção entre o direito aplicável a conflitos internacionais e a conflitos internos. Confira em: CASSESE, Antonio. International Criminal Law. $2^{\text {a }}$ ed. Oxford: Oxford University Press, 2008, p. 96.

${ }^{57}$ TPIEI, Prosecutor v. Tadić, IT-94-1, AC, Julgamento em 15 julho 1999. 
58 Eles compreendem, dentre outras ações, homicídio, extermínio, escravidão, tortura, deportação forçada, estupro e a perseguição de um grupo por motivos políticos, raciais, étnicos, religiosos ou culturais, além de incluir outros atos desumanos não especificados que causem grande sofrimento ou ofendam gravemente a integridade física e moral de uma pessoa. $^{59}$

Por sua vez, o crime de tortura adquiriu uma autonomia em relação aos crimes acima descritos, de modo que o ato de torturar configura crime internacional que prescinde da caracterização de crime de guerra ou crime contra a humanidade. Em outras palavras, a tortura pode ser considerada um crime internacional ainda que seja praticada fora de um contexto de guerra ou de uma prática estatal generalizada ou sistemática. Esse foi o resultado de uma longa evolução, para a qual contribuíram de forma proeminente a Convenção da ONU Sobre Tortura de 1984 e o trabalho de tribunais internacionais e domésticos em casos como Furundzija, Kunarac, Pinochet e Selmouni. ${ }^{60}$ Hoje pode-se afirmar que o torturador é um inimigo da humanidade (hostis humani generis). ${ }^{61}$ A noção de tortura também evoluiu no sentido de se tornar bastante ampla, não estando mais vinculada à ação de um agente estatal e consistindo, essencialmente, em um ato ou omissão que causa profunda dor ou sofrimento, físico ou mental, cometido com um propósito proibido. ${ }^{62}$ É interessante notar essa evolução

\footnotetext{
${ }^{58}$ CASSESE, Antonio. International Criminal Law. $2^{\mathrm{a}}$ ed. Oxford: Oxford University Press, 2008, p. 99.

${ }^{59}$ Estatuto de Roma, Artigo $7^{\circ}$ : : Crimes contra a Humanidade:

1. Para os efeitos do presente Estatuto, entende-se por "crime contra a humanidade", qualquer um dos atos seguintes, quando cometido no quadro de um ataque, generalizado ou sistemático, contra qualquer população
} civil, havendo conhecimento desse ataque:

a) Homicídio;

b) Extermínio;

c) Escravidão;

d) Deportação ou transferência forçada de uma população;

e) Prisão ou outra forma de privação da liberdade física grave, em violação das normas fundamentais de direito internacional;

f) Tortura;

g) Agressão sexual, escravatura sexual, prostituição forçada, gravidez forçada, esterilização forçada ou qualquer outra forma de violência no campo sexual de gravidade comparável;

h) Perseguição de um grupo ou coletividade que possa ser identificado, por motivos políticos, raciais, nacionais, étnicos, culturais, religiosos ou de gênero, tal como definido no parágrafo $3^{\circ}$, ou em função de outros critérios universalmente reconhecidos como inaceitáveis no direito internacional, relacionados com qualquer ato referido neste parágrafo ou com qualquer crime da competência do Tribunal;

i) Desaparecimento forçado de pessoas;

j) Crime de apartheid;

k) Outros atos desumanos de caráter semelhante, que causem intencionalmente grande sofrimento, ou afetem gravemente a integridade física ou a saúde física ou mental.

${ }^{60}$ TIPEI, Prosecutor v. Furundzija, IT-95-17/1, TC, Julgamento em 10 dezembro 1998; TIPEI, Prosecutor v. Kunarac et al., IT-96-23\&23/1, TC, Julgamento em 22 fevereiro 2001; House of Lords, Regina v. Bartle and the Commissioner of the Police for the Metropolis and others EX Parte Pinochet (Pinochet II), 24 março 1999, 20 HRLJ, (1999); Corte Européia de Direitos Humanos, Selmouni v. France, 7 julho 1999;

${ }^{61}$ US Court of Appeals, Second Circuit, Filartiga v. Peña-Irala, 30 junho 1980.

${ }^{62}$ CASSESE, Antonio (ed). The Oxford Companion to International Criminal Justice. Oxford: Oxford University Press, 2009. p. 538. 
na jurisprudência do TPIEI: inicialmente, no caso Furundzija, ${ }^{63}$ embora se tenha reconhecido a proibição da tortura como uma norma ius cogens, o tribunal entendeu haver a necessidade da participação de um agente estatal para a configuração do crime; posteriormente, no caso Kunarac, o tribunal reinterpretou a proibição da tortura no DIH e asseverou que "o ato de tortura e repreensível por si mesmo, independente de quem o comete, e não pode ser justificado em qualquer circunstância". ${ }^{64}$

O genocídio é a prática de um dos cinco atos descritos no art. $2^{\circ}$ da Convenção sobre o Genocídio de 1948 com o propósito de destruir, em todo ou em parte, um grupo nacional, étnico, racial ou religioso. É considerado o "crime dos crimes", ${ }^{65}$ expressão que resulta dos horrores ocorridos no século XX, dentre os quais se destaca o genocídio promovido por Hitler contra os judeus. Seu elemento distintivo é o elemento subjetivo que ele requer - o dolus specialis - que consiste na intenção de destruir um grupo específico. ${ }^{66}$ Por isso, afirma-se que o genocídio é um crime baseado na despersonalização da vítima, pois ela é perseguida não por suas características individuais, mas pelo simples fato de ser membro de um grupo. ${ }^{67}$

Finalmente, temos o crime de agressão, que foi primeiramente definido em 1945, no acordo que criou o Tribunal de Nuremberg. ${ }^{68}$ Seu elemento material se traduzia no planejamento, preparação, iniciação ou participação em uma guerra de agressão ou em violação de tratados ou garantias internacionais. Ocorre que, finda a Segunda Guerra Mundial, o crime de agressão caiu em profunda letargia. Fora a Resolução da Assembléia Geral da ONU de 1974, contendo a definição de agressão, ${ }^{69}$ o debate em torno da definição do

\footnotetext{
${ }^{63}$ TPIEI, Prosecutor v. Anto Furundzija. TC, 10 dezembro 1998 (TJ); AC, 21 julho 2000 (AJ).

${ }^{64}$ TPIEI, Prosecutor v. Dragoljub Kunarac and others. TC, 22 fevereiro 2001 (TJ), §§ 490-492.

${ }^{65}$ SCHABAS, William. Genocide in International Law: the Crime of Crimes. Cambridge: Cambridge University Press, 2000.

${ }^{66}$ TPIR, Prosecutor v. Akayesu, TC, Julgamento 2 setembro 1998, parágrafo 498.

${ }^{67}$ CASSESE, Antonio (ed). The Oxford Companion to International Criminal Justice. Oxford: Oxford University Press, 2009. p. 335.

${ }^{68}$ Acordo de Londres de 9 agosto 1945 estabelecendo o Tribunal Militar Internacional. O artigo 6(a) da Carta do Tribunal de Nuremberg, anexada ao acordo, previa: "Os seguintes atos são crimes sob a jurisdição do Tribunal para os quais haverá responsabilidade individual: (a) crimes contra a paz: nomeadamente planejar, preparar, iniciar ou participar em uma guerra de agressão, ou em uma guerra em violação de tratados internacionais, acordos ou garantias, ou, ainda, participar em um plano comum ou uma conspiração para a execução de qualquer dos atos anteriores".

${ }^{69}$ Resolução 3314(XXIX) de 14 dezembro 1974 da Assembléia Geral da ONU: Definição de Agressão.

Artigo 1. ${ }^{\circ}$ A agressão é o uso da força armada por um Estado contra a soberania, integridade territorial ou independência política de outro Estado, ou de qualquer forma incompatível com a Carta das Nações Unidas, tal Como decorre da presente Definição.

Artigo $3 .^{\circ}$ Considerar-se-á ato de agressão qualquer um dos atos a seguir enunciados, tenha ou não havido declaração de guerra, sob reserva das disposições do artigo $2 .^{\circ}$ e de acordo com elas:

a) A invasão ou o ataque do território de um Estado pelas forças armadas de outro Estado, ou qualquer ocupação militar, ainda que temporária, que resulte dessa invasão ou ataque, ou qualquer anexação mediante o uso da força do território ou de parte do território de outro Estado;
} 
conceito e, sobretudo, a respeito de quem seria o encarregado de determinar a ocorrência do crime, significou que desde o pós-guerra o crime de agressão não conseguiu ser aplicado na prática a indivíduos, embora tenham ocorrido diversas ocasiões em que Estados reconhecidamente praticaram atos de agressão. Essa situação está, contudo, prestes a mudar. Com efeito, o crime de agressão foi incluído no Estatuto do TPI, ainda que na época de sua assinatura não houvesse um consenso quanto à definição de agressão e o exercício da jurisdição do tribunal a seu respeito. ${ }^{70} \mathrm{Na}$ recente Conferência de Revisão do Estatuto de Roma, em Kampala, após longos debates, foi finalmente aprovada uma Resolução contendo uma definição do crime de agressão a ser incluída no Estatuto do TPI. ${ }^{71}$ Embora essa

b) O bombardeamento pelas forças armadas de um Estado, ou o uso de quaisquer armas por um Estado, contra o território de outro Estado;

c) O bloqueio dos portos ou da costa de um Estado pelas forças armadas de outro Estado;

d) $\mathrm{O}$ ataque pelas forças armadas de um Estado contra as forças armadas terrestres, navais ou aéreas, ou a marinha e aviação civis de outro Estado;

e) A utilização das forças armadas de um Estado, estacionadas no território de outro com o assentimento do Estado receptor, $\mathrm{cm}$ violação das condições previstas no acordo, ou o prolongamento da sua presença no território em questão após o termo do acordo;

f) $O$ fato de um Estado aceitar que o seu território, posto à disposição de outro Estado, seja utilizado por este para perpetrar um ato de agressão contra um terceiro Estado;

g) O envio por um Estado, ou em seu nome, de bandos ou de grupos armados, de forças irregulares ou de mercenários que pratiquem atos de força armada contra outro Estado de uma gravidade tal que sejam equiparáveis aos atos acima enumerados, ou o fato de participar de uma forma substancial numa tal ação.

$\mathrm{O}$ artigo $4^{\circ}$ da Resolução afirma que a definição não é exaustiva e que o Conselho de Segurança da ONU possui competência para determinar quando há uma agressão, verbis: Artigo $4 .^{\circ}$ - A enumeração dos atos mencionados acima não é exaustiva e o Conselho de Segurança poderá qualificar outros atos como atos de agressão de acordo com as disposições da Carta.

${ }^{70}$ Estatuto de Roma, Artigo 5(2): "O Tribunal poderá exercer a sua competência em relação ao crime de agressão desde que, nos termos dos artigos 121 e 123, seja aprovada uma disposição em que se defina o crime e se enunciem as condições em que o Tribunal terá competência relativamente a este crime. Tal disposição deve ser compatível com as disposições pertinentes da Carta das Nações Unidas."

${ }^{71}$ Resolução 6 da Conferência de Revisão do Estatuto de Roma, adotada em 11 junho 2010. No original, em inglês:

"1. Article 5, paragraph 2, of the Statute is deleted.

2. The following text is inserted after article 8 of the Statute:

Article 8 bis - Crime of aggression

1. For the purpose of this Statute, "crime of aggression" means the planning, preparation, initiation or execution, by a person in a position effectively to exercise control over or to direct the political or military action of a State, of an act of aggression which, by its character, gravity and scale, constitutes a manifest violation of the Charter of the United Nations.

2. For the purpose of paragraph 1, "act of aggression" means the use of armed force by a State against the sovereignty, territorial integrity or political independence of another State, or in any other manner inconsistent with the Charter of the United Nations. Any of the following acts, regardless of a declaration of war, shall, in accordance with United Nations General Assembly resolution 3314 (XXIX) of 14 December 1974, qualify as an act of aggression:

a) The invasion or attack by the armed forces of a State of the territory of another State, or any military occupation, however temporary, resulting from such invasion or attack, or any annexation by the use of force of the territory of another State or part thereof;

b) Bombardment by the armed forces of a State against the territory of another State or the use of any weapons by a State against the territory of another State;

c) The blockade of the ports or coasts of a State by the armed forces of another State;

d) An attack by the armed forces of a State on the land, sea or air forces, or marine and air fleets of another State; 
Resolução condicione o exercício da jurisdição do TPI em relação ao crime a uma decisão a ser tomada a partir do ano de 2017, um grande passo foi dado rumo à consolidação do crime de agressão no direito internacional penal e ao fortalecimento do direito à paz. ${ }^{72}$ Nas palavras de William A. Schabas, isso é uma metáfora para o fato de que o TPI e a justiça internacional penal são, parafraseando Victor Hugo, "uma ideia cujo tempo chegou - e nada pode parála". 73

e) The use of armed forces of one State which are within the territory of another State with the agreement of the receiving State, in contravention of the conditions provided for in the agreement or any extension of their presence in such territory beyond the termination of the agreement;

f) The action of a State in allowing its territory, which it has placed at the disposal of another State, to be used by that other State for perpetrating an act of aggression against a third State;

g) The sending by or on behalf of a State of armed bands, groups, irregulars or mercenaries, which carry out acts of armed force against another State of such gravity as to amount to the acts listed above, or its substantial involvement therein.

${ }^{72}$ Sobre o direito à paz, veja, do Conselho de Direitos Humanos da ONU a "Report of the Office of the High Commissioner on the outcome of the expert workshop on the right of peoples to peace". Documento A/HRC/14/38 de 17 março 2010.

${ }^{73}$ SCHABAS, William. The Kamapala Review Conference: A Brief Assessment. 17 junho 2010. Disponível em: http://humanrightsdoctorate.blogspot.com/2010/06/kampala-review-conference-brief.html. Acesso em: 25 junho 2010. 


\section{Capítulo 2. A Relação entre a Responsabilidade do Estado e do Indivíduo por Crimes Internacionais na Doutrina, nos Artigos da CDI e no Estatuto de Roma}

\subsection{Os Artigos da CDI, o Estatuto de Roma e a Indefinição da Relação}

As relações entre a responsabilidade do Estado e do indivíduo se tornaram relevantes na medida em que as novas instituições da justiça internacional começaram a lidar com temas pertinentes a ambas as formas de responsabilidade. Isso não passou despercebido pela CDI e tampouco pelos idealizadores do Estatuto de Roma.

À Comissão de Direito Internacional da ONU foi confiada a tarefa de criar um Projeto de Código de Crimes Contra a Paz e a Segurança da Humanidade, em paralelo aos artigos sobre a responsabilidade dos Estados. Nos anos oitenta, o Relator Especial encarregado de criar esse código optou por vinculá-lo ao antigo artigo 19 do projeto que tratava da responsabilidade dos Estados. Assim, a responsabilidade individual existiria apenas para as violações que fossem consideradas crimes internacionais pelo antigo artigo $19 .{ }^{74}$ No entanto, essa proposta foi rejeitada e a coordenação entre o projeto sobre a responsabilidade dos indivíduos e o projeto sobre a responsabilidade dos Estados foi deixada de lado. Nesse sentido, a CDI afirmou que:

A responsabilidade penal dos indivíduos não elimina a responsabilidade internacional dos Estados pelas consequências de atos cometidos por pessoas que atuam como órgãos ou agentes do Estado. Contudo, tal responsabilidade é de uma natureza diferente e pertence ao conceito tradicional de responsabilidade do Estado. A responsabilidade do Estado não pode ser regulada pelo mesmo regime que a responsabilidade penal dos indivíduos. ${ }^{75}$

Em suma, devido às controvérsias que o tema gerava e à falta de um acordo, a CDI, malgrado reconhecesse a existência de problemas concernentes à relação entre os dois tipos de responsabilidade, optou por inserir cláusulas de "sem prejuízo" nos dois projetos:

Projeto de Código de Crimes Contra a Paz e a Segurança da Humanidade de 1996:

Art. 4. O fato de o presente código prever a responsabilidade de indivíduos por crimes contra a paz e a segurança da humanidade é sem prejuízo a qualquer questão relativa à responsabilidade dos Estados no direito internacional.

\footnotetext{
${ }^{74}$ THIAM, Doudou. Third Report on the Draft Code of Crimes Against the Peace and Security of Mankind. YILC, Vol. II(1), 1983, p. 143-157.

${ }^{75}$ Comissão de Direito Internacional. Report on the Work of its 36th Session. YILC, Vol. II(2), 1984, p. 11.
} 
Artigos Sobre a Responsabilidade dos Estados por Atos Internacionalmente Ilícitos de 2001:

Art. 58. Estes artigos são sem prejuízo de qualquer questão relativa à responsabilidade individual de qualquer pessoa agindo em nome de um Estado. ${ }^{76}$

Dessas normas podem ser tiradas algumas conclusões: i) é reconhecida uma dualidade de regimes de responsabilidade no direito internacional (ou seja, há dois conjuntos de regras secundárias atinentes a crimes internacionais); ii) os dois regimes não são mutuamente excludentes; e iii) a relação precisa entre os dois tipos de responsabilidade não está definida, permanecendo aberta a desenvolvimentos futuros do direito internacional. ${ }^{77}$

Por sua vez, o Estatuto do TPI adotou uma posição semelhante à dos projetos da CDI, enunciando, no art. 25(4), que "nenhum dispositivo deste Estatuto relativo à responsabilidade individual afetará a responsabilidade dos Estados no direito internacional”. Ocorre que a redação desse artigo pode ser interpretada de maneira ligeiramente diferente das cláusulas "sem prejuízo". Isso porque, enquanto "sem prejuízo" enfatiza o fato de que um tipo de responsabilidade não exclui o outro, a expressão "não afetará" pode ser lida no sentido de que uma determinação sobre a responsabilidade de um indivíduo não deverá ser levada em conta para a aferição da responsabilidade do Estado, o que seria um grande equívoco, como se mostrará adiante.

A continuação deste artigo buscará preencher esse vazio normativo deixado pela CDI e pelo Estatuto de Roma, ensaiando os fundamentos de uma teoria que explique a relação entre a responsabilidade do indivíduo e do Estado no direito internacional.

2.2 Abordagens Teóricas à Relação entre a Responsabilidade do Indivíduo e do Estado por Crimes Internacionais

A bibliografia que trata da relação entre a responsabilidade do Estado e do indivíduo no direito internacional ainda é limitada e pontual - o tema é relativamente novo e, por isso, ainda pouco explorado, sendo que grande parte dos trabalhos que abordam a matéria o fazem em relação a um aspecto preciso da relação. Até o presente, talvez um dos únicos trabalhos a explorar o tema de forma abrangente é o livro de Beatrice I. Bonafè. ${ }^{78} \mathrm{~A}$ escassez de produção acadêmica sobre o assunto é consideravelmente maior na língua portuguesa, não

\footnotetext{
${ }^{76}$ Traduções do autor.

${ }^{77}$ BONAFÈ, Beatrice I. The Relationship Between State and Individual Responsibility for International Crimes. Leiden: Martinus Nijhoff Publishers, 2009, p. 35.

${ }^{78}$ BONAFE, Beatrice I. The Relationship Between State and Individual Responsibility for International Crimes. Leiden: Martinus Nijhoff Publishers, 2009.
} 
havendo, até o momento, notícia de livros dedicados exclusivamente à relação entre as duas formas de responsabilidade do direito internacional.

Bonafè propõe dois esquemas conceituais que podem ser aplicados à relação entre a responsabilidade do Estado e do indivíduo por crimes internacionais. O primeiro tem uma orientação voltada ao indivíduo, o segundo enfatiza o papel do Estado. Dessa forma, no esquema conceitual em que prevalece o indivíduo pressupõe-se a dissociação entre a conduta do Estado e a de seus órgãos e ressaltam-se as diferenças entre o direito internacional penal e a responsabilidade dos Estados. ${ }^{79}$ Nesse sentido, a responsabilidade do indivíduo é completamente separada e independente da responsabilidade do Estado. Por conseguinte, em sua versão radical, esse esquema acaba negando a própria relação entre a responsabilidade do indivíduo e do Estado, uma vez que não há conexão alguma entre elas. ${ }^{80}$

$\mathrm{O}$ segundo esquema conceitual, que enfatiza a responsabilidade do Estado, repousa sobre a presunção de identidade entre a conduta criminosa de um Estado e de seus órgãos, de tal modo que indivíduos só podem ser punidos quando suas condutas são atribuídas a um Estado. Em verdade, nessa visão apenas o Estado é responsável perante o direito internacional. A responsabilidade individual não é um regime à parte, mas uma consequência indireta e específica da responsabilidade do Estado. Também esse esquema, levado às últimas consequências, nega a relação entre a responsabilidade individual e a do Estado. ${ }^{81}$

Se a primeira concepção apregoa uma separação radical entre as duas formas de responsabilidade, a segunda sustenta uma fusão completa entre elas. Em ambos os casos, o resultado é que não há uma relação entre a responsabilidade do Estado e do indivíduo. ${ }^{82}$ Embora esses dois modelos não encontrem apoio na prática internacional, eles podem servir como parâmetros para uma teoria que explique a relação, que inevitavelmente se aproximará mais de um dos dois modelos, ao defender uma relação mais estreita ou mais larga entre as duas formas de responsabilidade.

2.2.1 Um conjunto de regras primárias, dois regimes de regras secundárias

Beatrice I. Bonafè sustenta que o único quadro capaz de explicar a prática internacional em sua generalidade é um esquema conceitual segundo o qual a responsabilidade do Estado e a do indivíduo surgem das mesmas normas primárias, mas são

\footnotetext{
${ }^{79}$ Id. Ibid. p. 63.

${ }^{80}$ Id. Ibid. p. 64.

${ }^{81}$ Id. Ibid. p. 66.

${ }^{82}$ Id. Ibid. p. 67.
} 
regidas por conjuntos diferentes de normas secundárias. ${ }^{83}$ Assim, a conduta criminosa que enseja tanto a responsabilidade do Estado como a do indivíduo é uma só e não pode ser qualificada de modo diverso (como legal ou ilegal) quando avaliada pela perspectiva da responsabilidade individual ou da responsabilidade do Estado.

Essa teoria visa a responder à necessidade de uma coordenação entre as duas formas de responsabilidade na prática internacional e de consistência na aplicação de algumas normas internacionais que concernem tanto à responsabilidade do Estado como à do indivíduo (e.g. legítima defesa). Em suma, Bonafè defende que há uma correspondência na avaliação dos elementos estruturais dos crimes internacionais para ambas as formas de responsabilidade. Há uma unidade no que concerne às normas primárias, que definem a conduta material proibida. Assim, uma vez constatada a execução de um crime, caberá aos dois conjuntos distintos de regras secundárias estabelecerem quem deve ser punido e qual sanção deve ser aplicada. A violação do direito material é, contudo, uma só e, por conseguinte, a conduta será ilícita independentemente do regime de responsabilidade que se queira utilizar.

Para apoiar sua teoria, Bonafè sugere que o julgamento da Corte Internacional de Justiça no Caso do Genocídio confirma a unidade no nível das regras primárias, ao utilizar como evidência para a atribuição de responsabilidade a um Estado o material elaborado pelo TPIEI para verificar a responsabilidade dos indivíduos. ${ }^{84}$ Outro caso que serviria de base para essa proposição é o de Darfur, uma vez que o TPI tem utilizado as constatações de fato da Comissão de Inquérito da ONU para se pronunciar sobre questões ligadas à responsabilidade individual. $^{85}$

É reconhecido que a relação entre as duas formas de responsabilidade é variável para os diferentes crimes. Bonafè classifica os crimes internacionais em três categorias, para fins descritivos: i) crimes individuais, definidos puramente em termos de conduta individual, como no caso de alguns crimes de guerra; ii) crimes de Estado, definidos rigorosamente em termos de conduta estatal, como o caso da agressão; e iii) crimes coletivos, caracterizados por condutas proibidas que só podem ser realizadas por uma coletividade (como, em geral, crimes contra a humanidade e genocídio). ${ }^{86}$ Enquanto os crimes de Estado apresentam uma relação

\footnotetext{
${ }^{83}$ Id. Ibid. p. 244.

${ }^{84}$ A Corte Internacional de Justiça concluiu, com base em elementos de prova utilizados no TPIEI, que o massacre de Srebrenica poderia ser qualificado de genocídio. Veja: Case Concerning the Application of the Convention on the Prevention and Punishment of the Crime of Genocide (Bósnia Herzegóvina v. Sérvia e Montenegro), Mérito, Julgamento 26 fevereiro 2007, parágrafos 296-297.

${ }^{85}$ Tribunal Penal Internacional, Prosecutor v. Ahmad Harun and Ali Kushayb, Pre-Trial Chamber, Julgamento 27 abril 2007, parágrafos 59 e 75.

${ }^{86}$ BONAFE, Beatrice I. The Relationship Between State and Individual Responsibility for International Crimes. Leiden: Martinus Nijhoff Publishers, 2009, p. 251-252.
} 
muito próxima entre os dois regimes de responsabilidade, os crimes individuais revelam uma relação mais distante, sendo que os crimes coletivos estariam no meio do caminho entre a aproximação e o afastamento.

2.2.2 Dois conjuntos de regras primárias, dois regimes de regras secundárias

A posição de Antonio Cassese diverge da de Beatrice I. Bonafè. Para o renomado internacionalista, "os dois regimes de responsabilidade são diferentes não apenas porque cada regime está ligado a normas internacionais primárias ou substantivas diferentes, mas também porque eles prevêem diferentes precondições da responsabilidade e consequências da responsabilidade". ${ }^{87}$ Em outras palavras, para Cassese a responsabilidade do Estado deriva da violação de normas de conduta diferentes das normas que criminalizam a conduta de indivíduos. Desse modo, um Estado pode cometer um ato que implique sua responsabilidade agravada sem que essa conduta seja necessariamente considerada ilegal pelo regime da responsabilidade individual.

No que tange ao crime de genocídio, Cassese defende que a responsabilidade do indivíduo está prevista no art. $3^{\circ}$ da Convenção Contra o Genocídio de $1948{ }^{88}$ e que a responsabilidade dos Estados deriva da obrigação do direito costumeiro de não cometer genocídio por uma política perseguida ou tolerada pelo Estado. ${ }^{89}$ Destarte, “as condições objetivas e subjetivas das quais dependem, respectivamente, a caracterização da responsabilidade do Estado e do indivíduo podem diferir e, de fato, diferem". ${ }^{90}$

Para exemplificar a divergência entre as teorias de Bonafè e Cassese, mister examinar a relação entre os dois regimes de responsabilidade pelo crime de agressão. Segundo Bonafè, a norma primária que proíbe o crime de agressão é uma só, havendo uma diferença apenas no nível de normas secundárias que regulam a responsabilidade do Estado e do indivíduo. Assim, o crime é definido em termos de ação estatal, de modo que a abertura de um processo penal

\footnotetext{
${ }^{87}$ CASSESE, Antonio. International Criminal Law. $2^{\mathrm{a}}$ ed. Oxford: Oxford University Press, 2008, p. 156. ${ }^{88}$ Art. $3^{\circ}$ : Serão punidos os seguintes atos:

a) O genocídio;

b) $\mathrm{O}$ acordo com vista a cometer genocídio;

c) O incitamento, directo e público, ao genocídio;

d) A tentativa de genocídio;

e) A cumplicidade no genocídio.

${ }^{89}$ Segundo Cassese, essa é a orientação seguida pela Comissão de Internacional de Inquérito para Darfur no documento Report of the UN International Commission of Inquiry on Darfur, UN doc. S/2005/60, parágrafos 439-522.

${ }^{90}$ CASSESE, Antonio. International Criminal Law. $2^{\mathrm{a}}$ ed. Oxford: Oxford University Press, 2008, p. 130.
} 
contra um indivíduo depende da prévia determinação da responsabilidade de um Estado por agressão. $^{91}$

Cassese rechaça esse entendimento e sustenta que "as regras costumeiras e os dispositivos de tratados que proíbem o uso ilegal da força como um ato internacionalmente ilícito são diferentes e mais amplos que as normas costumeiras que criminalizam a agressão". ${ }^{92}$ A agressão como um ato ilícito do Estado, tendo por consequência sua responsabilidade agravada, é qualquer violação grave ou em larga escala do artigo 2(4) da Carta da ONU não justificada pelos artigos 42 ou 51 do mesmo documento. ${ }^{93}$ Ademais, só há agressão por parte de um Estado quando o crime é cometido contra outro Estado. ${ }^{94}$ Já o direito internacional penal criminaliza o planejamento, a organização, a preparação ou a participação no uso da força de maneira grave e em larga escala de forma não legitimada pela Carta da ONU. Ele exige também o elemento subjetivo da conduta (dolo), o que não é previsto para a configuração da agressão como ato estatal ilícito. Além disso, a norma que criminaliza a agressão também penaliza atos agressivos de entidades não-estatais (como grupos terroristas, insurgentes, movimentos de libertação, etc.) contra Estados. ${ }^{95}$ Vale transcrever a justificativa de Cassese para tal separação das normas primárias que proíbem a agressão:

Já que este corpo do direito (direito internacional penal) é dedicado à penalização de transgressões individuais, não há o que impeça não seja a responsabilidade penal por agressão estendida a indivíduos que não pertençam ou não ajam em nome de um Estado. Se o propósito dessas normas do direito internacional é proteger a comunidade mundial de graves violações da paz, não há justificativa para que indivíduos agindo em nome de entidades não-estatais sejam imunes da responsabilidade penal por conduta agressiva. ${ }^{96}$

Em suma, a teoria que acolhe a existência de dois conjuntos de regras primárias, cada qual com seu respectivo regime de regras secundárias, tem a vantagem de alforriar o direito internacional penal de qualquer amarra com o direito da responsabilidade internacional dos Estados. Por outro lado, isso implica a possibilidade de uma descoordenação entre as duas formas de responsabilidade, o que pode levar a uma aplicação desuniforme e deficiente do direito internacional.

\footnotetext{
${ }^{91}$ BONAFÈ, Beatrice I. The Relationship Between State and Individual Responsibility for International Crimes . Leiden: Martinus Nijhoff Publishers, 2009, p. 249.

${ }^{92}$ CASSESE, Antonio. International Criminal Law. $2^{\mathrm{a}}$ ed. Oxford: Oxford University Press, 2008, p. 156.

${ }^{93}$ Id. Ibid. p. 156.

${ }^{94}$ Corte Internacional de Justiça, Legal Consequences of the Construction of a Wall in the Occupied Palestinian Territory, Opinião Consultiva, Julgamento 9 julho 2004, parágafo 139.

${ }^{95}$ CASSESE, Antonio. International Criminal Law. $2^{\mathrm{a}}$ ed. Oxford: Oxford University Press, 2008, p. 157.

${ }^{96}$ Id. Ibid. p. 157.
} 
Antes que se proceda a uma avaliação crítica mais detalhada das teorias de Bonafè e Cassese, será realizada uma análise sucinta da relação entre os dois regimes de responsabilidade na prática internacional. Essa análise tem o escopo de fornecer os elementos que indicarão qual teoria se mostra mais adequada à realidade. 


\section{Capítulo 3. A Relação entre a Responsabilidade do Estado e do Indivíduo por Crimes Internacionais na Prática Internacional}

\subsection{O elemento material dos crimes internacionais}

O elemento material ou objetivo de um crime internacional é a conduta criminosa. Por um lado, a responsabilidade agravada dos Estados por crimes internacionais depende da gravidade da conduta, uma vez que tal requisito está previsto no art. 40 dos Artigos da CDI. Por outro, a responsabilidade dos indivíduos por crimes internacionais surge, em grande parte dos casos, por ofensas cometidas de maneira sistemática ou em larga escala. O ponto de contato entre as duas formas de responsabilidade será tanto maior quanto mais o critério de gravidade da responsabilidade dos Estados se aproximar dos requisitos de "larga escala" e de "maneira sistemática" da responsabilidade individual.

Voltando ao exposto no item 1.1, a responsabilidade agravada dos Estados difere da responsabilidade ordinária porque ela exige que a violação da obrigação estabelecida por uma norma peremptória seja grave. ${ }^{97} \mathrm{O}$ art. 40(2) dos Artigos da CDI elucida que "uma violação é grave se envolver a falha grosseira ou sistemática do Estado responsável por cumprir a obrigação". Alguns crimes, como o genocídio e a agressão, já são, por definição, de natureza grave. ${ }^{98}$ Com relação a outros, como crimes de guerra, crimes contra a humanidade e a tortura, a gravidade da violação serve de critério para a atribuição de responsabilidade agravada aos Estados. Segundo Bonafè, esse critério significa que a violação deve ser mais que a execução coletiva de um crime internacional, ela deve ser um ataque sistemático a uma obrigação fundamental da comunidade internacional. ${ }^{99}$

O caso Velásquez, ${ }^{100}$ da Corte Interamericana de Direitos Humanos, é exemplar por demonstrar como o critério da gravidade pode ser aplicado na prática. Na hipótese, embora o caso tratasse de um único desaparecimento, a Corte concluiu que "o sequestro e desaparecimento de Manfredo Velásquez se encaixa na prática sistemática de desaparecimentos em Honduras", ${ }^{101}$ o que implica a responsabilidade agravada desse Estado.

\footnotetext{
97 JORGENSEN, Nina H. B. The Responsibility of States for International Crimes. Oxford: Oxford University Press, 2000, p. 106-116.

${ }^{98}$ Comissão de Direito Internacional. Report on the Work of its 53rd Session. YILC, Vol. II(2), 2001, p. 113.

${ }^{99}$ BONAFÈ, Beatrice I. The Relationship Between State and Individual Responsibility for International Crimes. Leiden: Martinus Nijhoff Publishers, 2009, p. 78.

${ }^{100}$ Corte Interamericana de Direitos Humanos, Velásquez Rodriguez case, Julgamento 21 julho 1989, Annual Report of the Inter-American Court of Human Rights, Series C, No. 7, 1990.

${ }^{101}$ Id. Ibid. p. 65.
} 
O foco não estava, portanto, no ato singular em questão, mas no padrão geral dos eventos relacionados a esse ato.

No que tange ao direito internacional penal, há crimes que não requerem que a conduta proibida seja executada em larga escala ou de maneira sistemática. Um único ato de tortura, por exemplo, pode ser o bastante para condenar um indivíduo, sem que isso implique a responsabilidade agravada do Estado. O caso Selmouni, ${ }^{102}$ da Corte Européia de Direitos Humanos, ilustra bem essa situação. Na ocasião, a Corte reconheceu a responsabilidade da França pela tortura praticada por um policial. Isso não basta, contudo, para atribuir responsabilidade agravada ao Estado, uma vez que o ato não fora parte de uma prática sistemática ou generalizada.

O mesmo vale para alguns crimes de guerra, que não prevêem o critério de gravidade ou sistematicidade da conduta para a configuração do crime. Para Bonafè, o conceito de gravidade aplicável a alguns crimes de guerra, como aos definidos como "violações graves" das Convenções de Genebra, não é um padrão operacional, mas uma característica atinente à natureza da norma primária. ${ }^{103}$

A relação entre a responsabilidade individual e do Estado é mais próxima, contudo, quando se trata de crimes contra a humanidade, genocídio e agressão. Enquanto os dois últimos são, pela própria natureza da norma primária, graves e sistemáticos, os crimes contra a humanidade trazem em sua definição os critérios de que devem ser cometidos "em larga escala" ou "de maneira sistemática". Nesses casos, quando o autor do crime age em nome de um Estado, é difícil negar que haverá concorrência entre a responsabilidade individual e a responsabilidade agravada do Estado.

Conclui-se, por conseguinte, que o elemento material de alguns crimes indica uma certa coincidência entre a responsabilidade do indivíduo e do Estado (crimes contra a humanidade, genocídio e agressão). No entanto, ele também sinaliza que nem todo crime individual é necessariamente um crime de Estado, ainda que o autor seja um órgão estatal. Alguns crimes de guerra e a tortura não guardam semelhança estrutural quando se compara a conduta de indivíduos com a conduta de Estados.

\footnotetext{
${ }^{102}$ Corte Européia de Direitos Humanos, Selmouni v. France, Julgamento 28 julho 1999.

${ }^{103}$ BONAFÈ, Beatrice I. The Relationship Between State and Individual Responsibility for International Crimes. Leiden: Martinus Nijhoff Publishers, 2009, p. 84.
} 
3.2 O elemento subjetivo dos crimes internacionais

O elemento subjetivo é essencial para a determinação da responsabilidade individual por crimes internacionais. Ele consubstancia o estado psicológico do autor do crime (mens rea) e é normalmente descrito como o dolo ou a culpa. Quanto à responsabilidade do Estado, não é certo que o elemento subjetivo, a culpa (fault), seja imprescindível para a configuração de um crime de Estado. A responsabilidade agravada dos Estados não exige, a princípio, a culpa como requisito para a aplicação desse regime de normas secundárias. ${ }^{104}$ Ocorre que alguns crimes, a exemplo do genocídio, trazem em sua definição a exigência de uma intenção específica (dolus specialis). A questão concernente à relação entre a responsabilidade individual e do Estado está em determinar até que ponto o elemento subjetivo do ponto de vista do direito internacional penal coincide com o elemento subjetivo da responsabilidade dos Estados.

Quando um Estado comete um crime que requer um dolo específico, esse dolo ou corresponde à mens rea do indivíduo que age em nome do Estado, ou é determinado de maneira mais objetiva, através de uma "culpa coletiva" que pode ser inferida do conjunto e do padrão de atos criminosos estatais. ${ }^{105}$ Dada a complexidade dos crimes que deflagram a responsabilidade agravada dos Estados, é difícil identificar a culpa estatal com o estado psicológico de indivíduos particulares. Isso pode ser possível quando se trata de crimes isolados, que importam a responsabilidade comum dos Estados. Porém, em casos graves, onde há envolvimento de todo o aparelho estatal, é complicado manter esse argumento. ${ }^{106}$ Com efeito, essa visão parece estar em consonância com o entendimento da CIJ, que afirmou, no Caso do Genocídio, que a culpa do Estado "pode ser estabelecida com base na existência de um plano comum, ou de um padrão consistente de conduta que indicaria a intenção". ${ }^{107}$

Se a responsabilidade agravada do Estado por crimes que requerem um dolo específico depende do exame da culpa do Estado, consistente em um plano comum ou em um padrão consistente de conduta, o dolo específico exigido para a determinação da responsabilidade individual se aproxima bastante, na prática, da aferição da culpa estatal pela grande relevância

\footnotetext{
${ }^{104}$ Veja art. 40 do Projeto da CDI. Comissão de Direito Internacional. Report on the Work of its 53rd Session. YILC, Vol. II(2), 2001, p. 112.

${ }^{105}$ BONAFÈ, Beatrice I. The Relationship Between State and Individual Responsibility for International Crimes. Leiden: Martinus Nijhoff Publishers, 2009, p. 123.

${ }^{106}$ Id. Ibid. p. 123.

${ }^{107}$ Corte Internacional de Justiça, Case Concerning the Application of the Convention on the Prevention and Punishment of the Crime of Genocide (Bósnia Herzegóvina v. Sérvia e Montenegro), Mérito, Julgamento 26 fevereiro 2007, parágrafo 376.
} 
que os tribunais penais internacionais têm dado ao "contexto geral criminoso" (general criminal context).

Bonafè divide os precedentes dos tribunais ad hoc referentes ao crime de genocídio em três grupos: i) casos em que não há um contexto geral criminoso e em que o acusado não possui intenção genocida; ii) casos em que há um contexto geral criminoso, mas o acusado não possui intenção genocida; e iii) casos em que há um contexto geral criminoso e em que o acusado possui o dolo específico genocida. ${ }^{108} \mathrm{O}$ interessante dessa classificação é que ela demonstra "não haver casos em que tenha sido determinada a intenção genocida do acusado sem que haja um contexto genocida mais amplo". ${ }^{109}$ A jurisprudência do TPIR é um ótimo exemplo dessa afirmação. Desde seu primeiro caso, ${ }^{110}$ houve a constatação geral de que houve um genocídio em Ruanda contra os Tutsis. ${ }^{111}$ Diversos acusados foram então condenados por esse crime a partir dessa verificação inicial, conjugada com a verificação do dolo individual de cada acusado com base em seus atos pessoais.

$\mathrm{O}$ argumento aqui apresentado indica que, malgrado a culpa do Estado não corresponder ao elemento psicológico da conduta do indivíduo, cujo foco está nas ações individuais, o modo pelo qual ambos são estabelecidos é semelhante, passando por uma avaliação de padrões de comportamento que indicam um contexto geral criminoso. Isso significa que há uma aproximação expressiva entre a responsabilidade dos Estados e dos indivíduos no que concerne ao elemento subjetivo da conduta de crimes que requerem uma intenção específica. Nas palavras de Beatrice I. Bonafè:

A ênfase posta na existência de um padrão sistemático de comportamento criminoso ou de uma política criminosa reduz dramaticamente a distância que a princípio caracteriza o estabelecimento da culpa de um Estado, por um lado, e da mens rea de um órgão estatal, por outro. $[\ldots]$

Quando as responsabilidades do Estado e dos indivíduos são investigadas com relação aos mesmos crimes, essa dimensão coletiva pode estabelecer um vínculo direto entre os dois regimes de responsabilidade por crimes internacionais, em particular no que concerne ao modo pelo qual o elemento psicológico é determinado. Ao menos quanto à conduta relevante,

\footnotetext{
${ }^{108}$ BONAFÈ, Beatrice I. The Relationship Between State and Individual Responsibility for International Crimes. Leiden: Martinus Nijhoff Publishers, 2009, p. 132-133.

${ }^{109}$ Id. Ibid. p. 134.

${ }^{110}$ Tribunal Penal Internacional para Ruanda, Prosecutor v. Akayesu, ICTR-96-4, TC, Julgamento 2 setembro 1998.

${ }^{111}$ A câmara de julgamento do tribunal afirmou, no caso mencionado que "há provas de que foi um grupo particular, os Tutsis, que foram alvejados. Claramente, as vítimas não foram escolhidas como indivíduos, mas porque pertenciam ao grupo referido." Mais adiante, conclui que "o fato de o genocídio ter ocorrido enquanto a RAF estava em conflito com a RPF não pode de modo algum ser considerado uma circunstância extenuante para o crime", $\S \S 124$ e 128.
} 
tanto a mens rea do acusado quanto a culpa do Estado pelos mesmos crimes serão provadas de forma semelhante, com foco no mesmo contexto coletivo criminoso. ${ }^{112}$

\subsection{Excludentes de ilicitude de crimes internacionais}

Outro ponto de aproximação entre os dois regimes de responsabilidade a ser explorado é a comparação entre as circunstâncias que excluem a ilicitude de um ato estatal e as causas de exclusão da responsabilidade criminal do indivíduo. ${ }^{113}$ Trata-se de definir se uma circunstância que afasta a responsabilidade do Estado pode ter repercussão no campo do direito internacional penal, ou mesmo se certa situação que possa excluir a ilicitude de um ato (como, por exemplo, coação irresistível ou força maior) deve ser interpretada no mesmo sentido em ambos os regimes de responsabilidade.

Dadas as limitações deste trabalho, apenas a questão da legítima defesa será explorada. Isto porque, primeiramente, ela talvez seja a que mais luz pode trazer à relação entre a responsabilidade do indivíduo e do Estado. Em segundo lugar, devido ao fato de que, quando há uma violação grave de uma norma peremptória por um Estado, ou seja, quando um Estado comete um crime, é quase impossível invocar circunstâncias que afastem a ilicitude, que são típicas de atos ilegais isolados. ${ }^{114}$ Para exemplificar esse argumento se pode imaginar um Estado genocida. Como poderá ele asseverar que praticou genocídio por força maior, por coação irresistível, ou mesmo por estar em um estado de necessidade? ${ }^{115}$ De fato, a CDI inseriu em seu projeto o artigo 26, que declara que "nada nesse capítulo afasta a ilicitude de qualquer ato de um Estado em desconformidade com uma obrigação proveniente de uma norma peremptória do direito internacional". Indiscutível, consequentemente, a afirmação de Bonafè: "uma conexão entre a responsabilidade do Estado e do indivíduo, no que tange às circunstâncias que afastam a ilicitude de um ato estatal e às causas de exclusão da responsabilidade criminal do indivíduo, é muito pouco provável". 116

\footnotetext{
${ }^{112}$ BONAFÈ, Beatrice I. The Relationship Between State and Individual Responsibility for International Crimes. Leiden: Martinus Nijhoff Publishers, 2009, p. 144-145.

${ }^{113}$ Veja, respectivamente, os arts. 20 a 27 do Projeto da CDI sobre a Responsabilidade dos Estados por Atos Internacionalmente Ilícitos e os arts. 31 a 33 do Estatuto do TPI.

${ }^{114}$ BONAFE, Beatrice I. The Relationship Between State and Individual Responsibility for International Crimes. Leiden: Martinus Nijhoff Publishers, 2009, p. 153.

${ }^{115}$ A mesma pergunta pode ser feita com relação às excludentes de ilicitude no caso de um indivíduo que comete genocídio ou crimes contra a humanidade. Com efeito, essas excludentes também não se aplicam à responsabilidade individual por genocídio e crimes contra a humanidade, pois "quando se trata dos crimes que violam brutalmente a dignidade humana, a própria ideia de uma justificativa é um insulto às vítimas". Confira em: FLETCHER, George P.; OHLIN Jens David. Defending Humanity: when force is justified and why. Nova Iorque: Oxford University Press, 2008, p. 124.

116 Id. Ibid. p. 153.
} 


\subsubsection{Legítima defesa}

Segundo a CDI, a legítima defesa tem significados distintos no âmbito da responsabilidade dos Estados e no da responsabilidade dos indivíduos ${ }^{117}$. Assim, a princípio, ela não deve ser interpretada do mesmo modo nos dois regimes de normas secundárias. No entanto, há autores que defendem que a mesma teoria de legítima defesa utilizada por regimes de responsabilização individual deva ser aplicada, com poucas ressalvas, às relações entre Estados. Nesse sentido, George P. Fletcher e Jens David Ohlin defendem que "o direito internacional relativo ao uso da força defensiva deve manter um paralelo com o direito interno". ${ }^{118}$ Há, portanto, um vasto campo a ser explorado no que tange à interpretação de causas excludentes da ilicitude de um ato em regimes diversos de responsabilização.

Nos sistemas de responsabilidade dos Estados e dos indivíduos no direito internacional, é difícil imaginar uma ocasião em que a legítima defesa possa ser invocada como justificativa para a comissão de um crime contra a humanidade ou de genocídio. Ainda assim, o crime de agressão e alguns crimes de guerra indicam que a legítima defesa pode ser um ponto de contato importante entre a responsabilidade do Estado e do indivíduo. ${ }^{119}$

O crime de agressão é o que melhor demonstra a ligação entre os dois regimes de responsabilidade. Com efeito, se, na linha de Bonafè, se admite que "tanto a responsabilidade do indivíduo como a do Estado surgem da mesma violação - de um ato estatal de agressão -, então a circunstância capaz de justificar a conduta do indivíduo e do Estado é a mesma". ${ }^{120}$

\footnotetext{
${ }^{117}$ Veja: Comissão de Direito Intenacional. Report on the Work of its 48th Session. Yearbook of the International Law Commission. 1996, vol. II (Parte Dois), p. 40 (tradução do autor): "É importante distinguir a noção de legítima defesa no contexto do direito penal da noção de legítima defesa no contexto do artigo 51 da Carta das Nações Unidas. A noção de legítima defesa no contexto do direito penal serve para excluir a responsabilidade de um indivíduo por um ato violento cometido contra outro indivíduo que seria considerado criminoso, como um homicídio. Em contraste, a noção de legítima defesa no contexto da Carta das Nações Unidas se refere ao uso da força legítima por um Estado no exercício de seu direito inerente de legítima defesa individual ou coletiva, de forma a não caracterizar agressão".

${ }^{118}$ FLETCHER, George P.; OHLIN Jens David. Defending Humanity: when force is justified and why. Nova Iorque: Oxford University Press, 2008, p. 86. A tese central dos autores gira em torno da interpretação do art. 51 da Carta da ONU conforme uma teoria de legítima defesa oriunda do direito penal doméstico. Isso leva os autores a interpretarem o art. 51 da Carta da ONU de modo a garantir o direito de legítima defesa a nações, e não a Estados, além de estendê-lo à defesa de terceiros. Embora o livro seja instigante e tenha provocado um fértil debate sobre a teoria de legítima defesa do direito internacional, as conclusões dos autores, como eles mesmos admitem, se chocam, a toda evidência, com a redação do art. 51 da Carta da ONU. Em verdade, admitir uma interpretação da legítima defesa no direito internacional nos termos do livro Defending Humanity nos remete à ideia de uma verdadeira "caixa de pandora", na medida em que permitiria uma gama muito mais ampla de justificativas para o uso da força em comparação ao que hoje é admitido pela maioria dos jusinternacionalistas.

${ }_{119}$ BONAFĖ, Beatrice I. The Relationship Between State and Individual Responsibility for International Crimes. Leiden: Martinus Nijhoff Publishers, 2009, p. 155.

${ }^{120}$ Id. Ibid. p. 156.
} 
Em outras palavras, se o crime de agressão, que enseja a responsabilidade criminal do indivíduo e a responsabilidade agravada do Estado, é descrito por uma única norma primária; se é verdade que indivíduos não são punidos por atos pessoais de agressão, mas por atos de agressão do Estado a que pertencem; ${ }^{121}$ e se na ausência da determinação de ocorrência de um ato de agressão por um Estado um indivíduo não pode ser punido por este crime; então, é lógico concluir que, com relação ao crime de agressão, "há apenas uma noção de legítima defesa que se aplica tanto à responsabilidade do Estado como à do indivíduo". ${ }^{122}$

Assim, quanto ao ponto, a relação entre os dois regimes de responsabilidade é tal que, perante um tribunal penal internacional, um réu acusado de agressão poderia ser inocentado ao provar que o Estado a que pertence agiu em legítima defesa. Isso pode levar a problemas práticos na aplicação do direito internacional, porquanto os tribunais hoje existentes ou julgam apenas Estados (como a CIJ e tribunais de direitos humanos) ou somente indivíduos (como os tribunais penais internacionais). Logo, é possível conceber situações desconfortáveis em que um tribunal penal poderia inocentar um réu pelo crime de agressão, ao constatar que o Estado agiu em legítima defesa, enquanto, com relação aos mesmos fatos, a Corte Internacional de Justiça poderia condenar o Estado por agressão. ${ }^{123}$

Essa possível divergência entre cortes que julgam Estados e tribunais que julgam indivíduos reforça a necessidade de uma teoria da relação entre os dois regimes de responsabilidade capaz de subsidiar a aplicação consistente do direito internacional. Por outro lado, ela aponta que haveria vantagens em tribunais penais internacionais que julgassem não só indivíduos, como também Estados. ${ }^{124}$ De todo modo, tendo em mente as enormes dificuldades políticas que obstaculizam a extensão da jurisdição de tribunais penais a Estados, a possibilidade de divergência na aplicação do direito internacional por tribunais diferentes não é necessariamente um problema. Muito pelo contrário, a dita "proliferação" de órgãos judiciais internacionais pode oferecer maior proteção aos direitos humanos, que poderão ser reivindicados perante diversas instâncias. Essa situação pode levar, ainda, a um

\footnotetext{
${ }^{121}$ Veja os comentários ao art. 16 do Projeto de Código de Crimes Contra a Paz e a Segurança da Humanidade da CDI. In: Comissão de Direito Internacional. Report on the Work of its $48^{\text {th }}$ Session. YILC, 1996, vol. II (Parte Dois), p. 43.

${ }^{122}$ BONAFĖ, Beatrice I. The Relationship Between State and Individual Responsibility for International Crimes. Leiden: Martinus Nijhoff Publishers, 2009, p. 156.

${ }^{123}$ Essa questão ainda não surgiu na prática porque, desde os julgamentos dos grandes criminosos da $2^{\text {a }}$ Guerra Mundial, nenhum indivíduo jamais foi julgado por agressão por um tribunal internacional. Isso está prestes a mudar, uma vez que a Conferência de Revisão do Estatuto do TPI realizada este ano aprovou uma definição do crime de agressão e estabeleceu as condições para o exercício da jurisdição do TPI em relação a este crime. Desse modo, o conflito entre tribunais aqui concebido não é algo apenas teórico, uma vez que já há no direito internacional a possibilidade de isso vir a ocorrer em um futuro próximo.

${ }_{124}$ Neste sentido, veja: JORGENSEN, Nina H. B. The Responsibility of States for International Crimes. Oxford: Oxford University Press, 2000, p. 216.
} 
desenvolvimento mais democrático do direito internacional, na medida em que instituições distintas passam a aplicar as mesmas regras, o que pode levar a um profícuo diálogo institucional. $^{125}$

\subsection{Crimes Internacionais em Espécie}

\subsubsection{Genocídio}

A definição do crime de genocídio utilizada amplamente na prática internacional é a contida na Convenção para a Prevenção e Repressão ao Crime de Genocídio, de 1948. Ela descreve cinco condutas que caracterizam genocídio quando cometidas com a intenção de destruir, no todo ou em parte, um grupo nacional, étnico, racial ou religioso:

i) assassinato de membros do grupo;

ii) atentado grave à integridade física e mental de membros do grupo;

iii) submissão deliberada do grupo a condições de existência que acarretarão a sua destruição física, total ou parcial;

iv) medidas destinadas a impedir os nascimentos no seio do grupo;

v) transferência forçada das crianças do grupo para outro grupo. ${ }^{126}$

Originalmente, a Convenção contra o Genocídio tinha dois objetivos: i) obrigar os Estados a criminalizarem o genocídio e punirem os perpetradores deste crime; e ii) promover a cooperação judicial para a supressão do genocídio. ${ }^{127}$ A Convenção não tinha a intenção de estabelecer a responsabilidade dos Estados pelo crime de genocídio, uma vez que a noção de que Estados podem cometer crimes não era aceita na época de elaboração da Convenção.

Assim, as condutas previstas na Convenção de 1948 são descritas em termos estritamente individuais, de modo que, abstratamente, é possível que um único indivíduo, agindo de maneira independente, possa cometer o crime de genocídio. Nesse sentido, a existência de um plano genocida ou de uma organização a serviço de tal plano não é um requisito do crime de genocídio. ${ }^{128}$ Pode-se imaginar a situação, por exemplo, em que um anti-semita andando pelas ruas de Londres mata os três primeiros judeus que ele encontrar,

\footnotetext{
${ }^{125}$ Marcelo Neves fala em um "aprendizado recíproco que pode ocorrer em face da solução de casos jurídicos nos quais duas (ou mais) ordens estejam envolvidas". Veja: NEVES, Marcelo. Transconstitucionalismo. São Paulo: WMF Martins Fontes, 2009, p. 126.

${ }^{126}$ Convenção para a Prevenção e a Repressão ao Crime de Genocídio. Texto conforme o Decreto No 30.822 , de 6 de maio de 1952.

${ }^{127}$ CASSESE, Antonio. On the Use of Criminal Law Notions in Determining State Responsibility for Genocide. Journal of International Criminal Justice, n. 5, 2007, p. 876.

${ }^{128}$ TPIEI, Prosecutor v. Jelisic, TC, Julgamento 14 dezembro 1999, parágrafo 100.
} 
com a intenção de matar todo o povo judeu. ${ }^{129}$ Segundo uma interpretação literal da Convenção de 1948, ele cometeu genocídio.

No entanto, conforme indica Bonafè, "historicamente, o genocídio sempre foi perpetrado por grupos, ou melhor, por Estados". ${ }^{130}$ Desse modo, o grande problema do direito internacional penal foi descrever em termos de conduta individual um crime que é, em sua essência, coletivo. Essa natureza coletiva não foi traduzida, contudo, em um elemento preciso na definição do crime. ${ }^{131}$ Nas palavras de Ohlin e Fletcher, o Estatuto de Roma, ao dispor sobre o crime de genocídio, "claramente se desconstrói; por um lado, ele pretende tratar da responsabilidade individual, por outro, no entanto, ele acentua o papel da ação coletiva na comissão de crimes que afetam toda a comunidade internacional”. ${ }^{132}$

Se na teoria o genocídio é descrito em termos individuais, na prática internacional a sua natureza coletiva é fundamental para se atribuir responsabilidade por este crime. Um bom exemplo da importância do caráter coletivo do genocídio é encontrado na jurisprudência do Tribunal Penal Internacional para Ruanda. Com efeito, a Câmara de Apelação do Tribunal reconheceu como fato notório a ocorrência do genocídio em Ruanda. ${ }^{133}$ Uma vez reconhecido o contexto geral criminoso em Ruanda, em 1994, a tarefa do Procurador passou a ser a de provar a participação de cada indivíduo neste contexto genocida. Há aqui uma ligação clara entre a responsabilidade do Estado e do indivíduo por genocídio. O contexto geral criminoso, fundamental inicial para a atribuição de responsabilidade ao indivíduo, aponta, concomitantemente, para a responsabilidade agravada do Estado. No caso de Ruanda, “é difícil negar que o reconhecimento judicial do genocídio, somado ao fato de que o TPIR condenou oficiais de alto escalão do Estado, indica a responsabilidade agravada do Estado". 134

O elemento subjetivo do crime de genocídio, isto é, o dolus specialis de eliminação de um grupo, também corrobora a tese aqui defendida, de que o genocídio, por sua natureza coletiva, aproxima a responsabilidade do indivíduo da do Estado, de forma que, quando o

\footnotetext{
${ }^{129}$ Uma hipótese semelhante é sugerida em: FLETCHER, George P.; OHLIN Jens David. Defending Humanity: when force is justified and why. Nova Iorque: Oxford University Press, 2008, p. 192.

${ }^{130}$ BONAFĖ, Beatrice I. The Relationship Between State and Individual Responsibility for International Crimes. Leiden: Martinus Nijhoff Publishers, 2009, p. 104.

${ }^{131}$ FLETCHER, George P.; OHLIN Jens David. Reclaiming the Fundamental Principles of Criminal Law in the Darfur Case. Journal of International Criminal Justice, n. 3, 2005, p. 546.

${ }^{132}$ FLETCHER, George P.; OHLIN Jens David. Defending Humanity: when force is justified and why. Nova Iorque: Oxford University Press, 2008, p. 193.

${ }^{133}$ TPIR, Prosecutor v. Karemera et al., AC, Decision on Prosecutor's Interlocutory Appeal of Decision on Judicial Notice, Julgamento 16 junho 2006.

${ }^{134}$ BONAFÈ, Beatrice I. The Relationship Between State and Individual Responsibility for International Crimes. Leiden: Martinus Nijhoff Publishers, 2009, p. 107.
} 
grupo criminoso é o próprio Estado (e não um ator não-estatal), não há como deixar de atribuir responsabilidade simultaneamente aos indivíduos que cometeram genocídio e ao Estado que eles controlam, na forma agravada.

Bonafè divide os casos de genocídio julgados em cortes internacionais em três grupos, utilizando como critério o estabelecimento do dolo especial do genocídio. O primeiro grupo compreende casos em que não foi reconhecido um contexto geral criminoso e que os acusados não tinham intenção genocida. ${ }^{135} \mathrm{O}$ segundo grupo reúne casos em que foi estabelecido um contexto geral criminoso, mas os acusados não possuíam intenção genocida. ${ }^{136} \mathrm{O}$ último grupo se refere aos casos onde foi constatado um contexto geral criminoso e em que os acusados tinham intenção genocida. ${ }^{137} \mathrm{O}$ que sobressai dessa interessante análise, conforme já indicado no item 3.2, é a revelação de que "não há casos em que foi reconhecida a intenção genocida do acusado na ausência de um contexto genocida mais amplo". ${ }^{138}$ Dessa forma, é possível afirmar que a mens rea do crime de genocídio, ou seja, seu elemento subjetivo, tem sido estabelecida de uma forma mais objetiva, levando em consideração o contexto geral em que se dá a conduta individual. O elemento subjetivo da conduta do Estado também é estabelecido de forma objetiva, face ao contexto criminoso dos atos estatais. Assim, com relação a um mesmo evento, a determinação do contexto geral genocida é feita de forma similar e é fundamental tanto para a atribuição de responsabilidade aos indivíduos como ao Estado.

Diante do exposto, pode-se dizer que casos isolados, sem o envolvimento de um plano maior ou de uma coletividade, como o exemplo do anti-semita acima mencionado, não são adequados para explicar o crime de genocídio no direito internacional. O crime de genocídio deve ser interpretado como um crime coletivo, ${ }^{139}$ de forma que, salvo a possibilidade de ser perpetrado por grupos não-estatais, sua ocorrência invariavelmente implicará a responsabilidade agravada do Estado e a responsabilidade individual daqueles que participaram ou contribuíram para o crime. A norma violada será a mesma em ambos os

\footnotetext{
${ }^{135}$ Exemplos: TPIEI, Prosecutor v. Jelisic, Prosecutor v. Stakic, Prosecutor v. Brdanin, Prosecutor v. Krajisnik. ${ }^{136}$ Exemplos: TPIEI, Prosecutor v. Krstic, Prosecutor v. Blagojevic and Jokic, Prosecutor v. Krstic.

${ }^{137}$ Exemplos: TPIR, Prosecutor v. Rutaganda, Prosecutor v.Kayishema e Ruzindana, Prosecutor v. Ndindabahizi, Prosecutor v. Simba.

${ }^{138}$ BONAFĖ, Beatrice I. The Relationship Between State and Individual Responsibility for International Crimes. Leiden: Martinus Nijhoff Publishers, 2009, p. 134.

${ }^{139}$ Segundo Fletcher e Ohlin, "nosso entendimento comum do genocídio, baseado no paradigma histórico de Auschwitz, deriva de hostilidades enraizadas entre grupos. A essência do Holocausto foi uma nação visando à eliminação de outra. Alguns indivíduos foram especialmente culpados e submetidos a julgamento por homicídio, mas o pano de fundo coletivo genocida (collective eliminationist background) informou e dirigiu suas ações". Em: FLETCHER, George P.; OHLIN Jens David. Defending Humanity: when force is justified and why. Nova Iorque: Oxford University Press, 2008, p. 192.
} 
casos, havendo uma diferença apenas nas normas secundárias de cada regime de responsabilidade.

O julgamento da Corte Internacional de Justiça no caso do Genocídio confirma essa unidade no nível de regras primárias. Com efeito, a Corte afirmou expressamente que um Estado pode ser responsabilizado por genocídio, bem como pelos atos enumerados no art. $3^{\circ}$ da Convenção de 1948, ${ }^{140}$ da mesma forma que um indivíduo. Infelizmente, contudo, a CIJ não aprofundou a questão da relação entre a responsabilidade do Estado e dos indivíduos, se limitando a confirmar a dualidade de regimes de responsabilidade no direito internacional e a independência de cada um:

A Corte observa que a dualidade de responsabilidade continua a ser um aspecto constante do direito internacional. Este aspecto se reflete no artigo $25, \S 4^{\circ}$, do Estatuto de Roma do Tribunal Penal Internacional, agora aceito por 104 Estados [...]

A Corte conclui que a responsabilidade do Estado pode emanar da Convenção por genocídio e cumplicidade, sem que um indivíduo tenha sido condenado por esse crime. ${ }^{141}$

A CIJ teve o mérito de afirmar, pela primeira vez, que um Estado pode cometer genocídio e pode ser responsabilizado por este crime. Também merece aplausos por confirmar a existência dos dois regimes de responsabilidade no direito internacional. Entretanto, nos termos em que concluiu a questão da relação entre a responsabilidade do Estado e do indivíduo, ressaltando a independência de ambas, pecou por não explicitar a íntima ligação entre as duas formas de responsabilidade. Se um chefe de Estado é condenado pelo crime de genocídio, tendo o tribunal que o julgou concluído que havia uma política genocida estatal, é difícil negar que o Estado também mereça ser responsabilizado pelo crime. Por outro lado, se a CIJ reconhece a responsabilidade agravada de um Estado por genocídio, certamente vários agentes estatais deverão ser punidos pelos mesmos fatos.

Para Cançado Trindade, "não há um impedimento judicial para a determinação concomitante da responsabilidade internacional do Estado e da responsabilidade penal internacional do indivíduo, apesar do desenvolvimento insuficiente da matéria”. ${ }^{142}$ Uma vez constatada a natureza coletiva do genocídio, e ressaltado que o modo pelo qual os tribunais

\footnotetext{
${ }^{140}$ Case Concerning the Application of the Convention on the Prevention and Punishment of the Crime of Genocide (Bósnia Herzegóvina v. Sérvia e Montenegro), Mérito, Julgamento 26 fevereiro 2007, parágrafos 179181.

${ }^{141}$ Id. Ibid. parágrafos 173 e 182.

${ }^{142}$ CANÇADO TRINDADE, Antônio Augusto. Complementarity between State responsibility and individual responsibility for grave violations of human rights: the crime of State revisited. In: RAGAZZI, Maurizio (ed). International Responsibility Today: Essays in Memory of Oscar Schachter. Leiden: Martinus Nijhoff Publishers, 2005 , p. 258.
} 
determinam a ocorrência do crime é semelhante tanto para Estados como para indivíduos, é de se esperar que o direito internacional evolua no sentido de possibilitar a determinação concomitante da responsabilidade individual e do Estado. ${ }^{143}$ Há uma obrigação internacional de não cometer genocídio que vale tanto para indivíduos quanto para Estados. Assim, é inconcebível que, quanto aos mesmos atos, uns sejam punidos e outros não. A concepção compartimentalizada dos dois regimes de responsabilidade, espelhada no julgamento da CIJ, leva apenas à “erradicação parcial da impunidade". 144

\subsubsection{Crimes Contra a Humanidade}

Há um consenso de que os crimes contra a humanidade não são eventos esporádicos ou isolados, mas crimes de acentuada gravidade que fazem parte de uma prática generalizada ou sistemática de atrocidades. ${ }^{145}$ A ligação entre a responsabilidade do Estado e a dos indivíduos por crimes contra a humanidade se encontra justamente nos requisitos de "generalidade" e "sistematicidade" das condutas. Além disso, o Estatuto de Roma prevê que o ataque generalizado ou sistemático deve se dar "de acordo com a política de um Estado ou de uma organização de praticar esses atos ou tendo em vista a prossecução dessa política". ${ }^{146}$

Bonafè explica que os requisitos de "generalidade" e "sistematicidade" podem ser avaliados, perante um caso concreto, ou a partir de uma perspectiva individualizada, ou com ênfase no padrão dos ataques contra a população civil e no fato de ser o acusado parte do grupo responsável por tais ataques. ${ }^{147} \mathrm{~A}$ jurisprudência dos tribunais ad hoc tem seguido majoritariamente a segunda corrente, o que implica uma aproximação entre a responsabilidade do Estado e dos indivíduos. ${ }^{148}$

Nesse sentido, o TPIEI afirmou que os atos do acusado não precisam ser generalizados ou sistemáticos, sendo esses requisitos aplicáveis apenas ao ataque contra a população civil

\footnotetext{
${ }^{143}$ Id. Ibid. p. 268. Há que se ressaltar, contudo, que, no presente, a determinação concomitante da responsabilidade de indivíduos e Estados encontra um óbice na estrutura dos tribunais internacionais, que ou julgam Estados ou indivíduos. A extensão da jurisdição de um tribunal como o TPI para abranger Estados, ou mesmo outros atores internacionais (como empresas e outros grupos não estatais), ainda é um grande desafio. $\mathrm{O}$ mesmo pode ser dito da eventualidade de um tribunal de direitos humanos, ou da Corte Internacional de Justiça, se pronunciar sobre a responsabilidade de indivíduos. Além da questão teórica relativa aos dois sistemas de responsabilidade, há uma dificuldade prática que resulta da estrutura atual dos órgãos jurisdicionais internacionais.

${ }^{144}$ Id. Ibid. p. 268.

${ }^{145}$ Veja, dentre outros: BETTATI, Mario. Le crime contre l'humanité. In: HERVÉ, Ascensio; DECAUX, Emmanuel; PELLET, Alain (eds.). Droit International Pénal. Paris: Pedone, 2000.

${ }^{146}$ Estatuto de Roma, art. 7(2)(a).

${ }^{147}$ BONAFÈ, Beatrice I. The Relationship Between State and Individual Responsibility for International Crimes. Leiden: Martinus Nijhoff Publishers, 2009, p. 98-99.

${ }^{148}$ Id. Ibid. p. 99.
} 
como um todo. ${ }^{149}$ Assim, um único ato pode ser um crime contra a humanidade, desde que se encaixe em um contexto geral criminoso. ${ }^{150}$ Este contexto geral criminoso, que caracteriza a generalidade ou sistematicidade do ataque, é o elemento utilizado pelos tribunais internacionais para equacionar ações individuais com crimes coletivos - ele representa "a ligação entre a criminalidade individual e a coletiva". ${ }^{151}$

Quando a conduta de um indivíduo não é, por si só, um ataque generalizado ou sistemático, as cortes penais internacionais costumam empregar uma análise em duas etapas. ${ }^{152}$ A primeira consiste em determinar o contexto geral criminoso, a segunda em constatar se a conduta individual do acusado se encaixa nesse contexto. Bonafè levanta então a questão sobre "se o estabelecimento da responsabilidade individual por crimes contra a humanidade necessariamente corresponde ao reconhecimento de um ato ilícito grave, como definido pelas regras da responsabilidade agravada do Estado". ${ }^{153}$

É certo que crimes contra a humanidade podem ser cometidos por atores não-estatais, como grupos terroristas ou secessionistas. Contudo, quando há um envolvimento do aparelho estatal, é correto afirmar que a verificação da existência de um contexto geral criminoso, ou seja, de um ataque generalizado ou sistemático contra a população civil, deve acarretar a responsabilidade agravada do Estado. Como no crime de genocídio, malgrado não haja uma sobreposição absoluta entre a responsabilidade do Estado e a dos indivíduos (devido à possibilidade de perpetração por atores não-estatais), sempre que esses crimes forem cometidos por órgãos estatais, ou com o apoio e o suporte de um Estado, deve haver uma determinação concomitante de responsabilidade, tanto para o Estado como para os indivíduos envolvidos. Essa conclusão é apoiada por Bonafè, que ressalta:

Pode ser relevado que os tribunais penais internacionais cada vez mais estabelecem o pré-requisito de crimes contra a humanidade se referindo ao contexto geral criminoso ao invés da conduta pessoal do acusado, isto é, com relação a fatos que podem ser vistos como graves segundo o regime da responsabilidade agravada do Estado. Como uma questão de interpretação legal, o requisito de gravidade dos crimes contra a humanidade se refere ao contexto geral criminoso, e, portanto, é estabelecido de maneira muito similar com respeito tanto à responsabilidade do Estado como à do indivíduo. ${ }^{154}$

\footnotetext{
149 TPIEI, Prosecutor v. Kunarac et al., TC, Julgamento 22 fevereiro 2001, parágrafo 431.

${ }^{150}$ BONAFÈ, Beatrice I. The Relationship Between State and Individual Responsibility for International Crimes. Leiden: Martinus Nijhoff Publishers, 2009, p. 99.

${ }^{151}$ Id. Ibid. p. 100.

${ }^{152}$ Id. Ibid. p. 103.

${ }^{153}$ Id. Ibid. p. 103.

${ }^{154}$ Id. Ibid. p. 103-104.
} 


\subsubsection{Crimes de Guerra}

Conforme exposto no início deste trabalho, crimes de guerra são violações graves de normas costumeiras ou de tratados pertencentes ao direito internacional humanitário (DIH). ${ }^{155}$ Diferentemente dos crimes contra a humanidade, a caracterização de um crime de guerra independe de ele ser ou não parte de uma política ou de uma prática sistemática coletiva. ${ }^{156} \mathrm{~A}$ prática dos tribunais internacionais, sobretudo do TPIEI, demonstra que os crimes de guerra são interpretados tendo em vista a conduta pessoal dos acusados, segundo uma concepção individualista que dissocia a responsabilidade do Estado da dos indivíduos. De fato, o TPIEI afirmou que "as obrigações dos indivíduos perante o direito internacional humanitário são independentes e se aplicam sem prejuízo de qualquer questão de responsabilidade dos Estados no direito internacional". ${ }^{157}$

A princípio, portanto, relembrando a classificação dos crimes internacionais proposta por Bonafè (veja item 2.2.1), os crimes de guerra seriam classificados como crimes individuais, isto é, aqueles definidos puramente em termos de conduta individual. No entanto, a própria Bonafè argumenta que certos crimes internacionais "pressupõem a existência de um exército regular", ${ }^{158}$ ou de um aparelho estatal. Exemplos desses crimes de guerra são fartos nos documentos internacionais: i) "compelir um prisioneiro de guerra ou outra pessoa sob proteção a servir nas forças armadas de uma potência inimiga"; ${ }^{159}$ ii) "privação intencional de um prisioneiro de guerra ou de outra pessoa sob proteção do seu direito a um julgamento justo e imparcial"; ${ }^{160}$ iii) "utilizar veneno ou armas envenenadas"; ${ }^{161}$ iv) "recrutar ou alistar menores de 15 anos nas forças armadas nacionais ou utilizá-los para participar ativamente nas hostilidades". 162

Os crimes acima citados, bem como diversos outros, não são descritos em termos de condutas individuais, mas sim coletivas - ou mesmo estatais. Destarte, há uma cisão nos crimes de guerra, uns referindo-se a atos individuais (ex: matar pessoas protegidas; tortura; estupro;), outros a ações coletivas (ex: provocar deliberadamente a inanição da população civil como método de guerra). Fletcher e Ohlin vão além e defendem que a transição histórica

\footnotetext{
${ }^{155}$ CASSESE, Antonio. International Criminal Law. $2^{\text {a }}$ ed. Oxford: Oxford University Press, 2008, p. 81.

${ }^{156}$ Nesse sentido, veja o julgamento do TPIEI, Prosecutor v. Tadic, TC, Julgamento 7 maio 1997, parágrafo 573.

${ }^{157}$ Id. Ibid. parágrafo 573.

${ }^{158}$ BONAFÈ, Beatrice I. The Relationship Between State and Individual Responsibility for International Crimes. Leiden: Martinus Nijhoff Publishers, 2009, p. 92.

${ }^{159}$ Estatuto de Roma, art. 8 (2)(v).

${ }^{160}$ Estatuto de Roma, art. 8 (2)(vi).

${ }^{161}$ Estatuto de Roma, art. 8 (2)(xvii).

${ }^{162}$ Estatuto de Roma, art. 8 (2)(xxvi).
} 
das Convenções de Haia e de Genebra ao Estatuto de Roma intensificou a dimensão coletiva dos crimes de guerra. ${ }^{163}$ Segundo os professores de Columbia, o Estatuto de Roma é um ótimo exemplo de uma desconstrução, na linha de Jacques Derrida, porquanto "o texto do Estatuto se esforça para definir a responsabilidade individual, mas se sabota ao afirmar o oposto do que pretende sustentar". ${ }^{164}$

Com efeito, o artigo $8^{\circ}$ do Estatuto do TPI dispõe que "o Tribunal terá competência para julgar os crimes de guerra, em particular quando cometidos como parte integrante de um plano ou de uma política ou como parte de uma prática em larga escala desse tipo de crimes" (grifei). Fica evidente, por conseguinte, a ênfase dada ao caráter coletivo da conduta, o que implica uma aproximação entre a responsabilidade do Estado e dos indivíduos também quanto aos crimes de guerra. Embora a prática internacional ainda seja firme no sentido de tratar certos crimes de guerra em termos puramente individuais, de forma independente da responsabilidade do Estado, uma grande parte desses crimes está intimamente ligada à atuação estatal, de forma que a atribuição de responsabilidade a um indivíduo passaria pela determinação de aspectos cruciais para a atribuição de responsabilidade ao Estado.

Concluindo, os crimes de guerra, no que tange à relação entre os dois regimes de responsabilidade, devem ser divididos em dois grupos. O primeiro reúne os crimes puramente individuais, que independem da responsabilidade do Estado e não guardam correlação com esta. O segundo grupo é o dos crimes de guerra coletivos, que pressupõem um exército regular ou uma máquina estatal para sua realização. Nesses casos, a atribuição de responsabilidade a indivíduos e a Estados tem como base a violação das mesmas normas primárias, sendo idênticos os elementos que caracterizam o ato ilícito. Quanto ao ponto, a prática internacional ainda é bastante escassa, ${ }^{165}$ merecendo um desenvolvimento que realce a conexão entre a responsabilidade individual e a estatal, tendo em vista o mesmo contexto criminoso da qual ambas decorrem.

\subsubsection{Agressão}

Os recentes desenvolvimentos do direito internacional penal, com destaque para a Conferência de Revisão do Estatuto de Roma, ocorrida em Kampala, em junho de 2010,

\footnotetext{
${ }^{163}$ FLETCHER, George P.; OHLIN Jens David. Defending Humanity: when force is justified and why. Nova Iorque: Oxford University Press, 2008, p. 191.

${ }^{164}$ Id. Ibid. p. 187.

${ }^{165}$ BONAFE, Beatrice I. The Relationship Between State and Individual Responsibility for International Crimes. Leiden: Martinus Nijhoff Publishers, 2009, p. 94.
} 
confirmaram de modo inegável a estreitíssima relação entre a responsabilidade do Estado pelo crime de agressão e a responsabilidade dos indivíduos pelo mesmo crime. Ao contrário do que sustentou Cassese, que fala da "necessidade de separar a responsabilidade penal dos indivíduos da responsabilidade dos Estados”, ${ }^{166}$ a definição que será incluída no Estatuto do TPI traz em sua essência os mesmos elementos da norma costumeira de direito internacional que definem o que seja agressão para fins de responsabilidade do Estado.

A comparação entre a Resolução 3314 (XXIX) da Assembléia Geral da ONU, de 1974, que define o crime de agressão para Estados, e a nova definição do Estatuto de Roma, voltada a indivíduos, ilustra perfeitamente os laços entre as duas formas de responsabilidade. A Resolução 3314 (XXIX) prevê o seguinte:

Agressão é o uso da força armada por um Estado contra a soberania, a integridade territorial ou independência política de outro Estado, ou de qualquer forma incompatível com a Carta das Nações Unidas, tal como decorre da presente definição.

Por sua vez, a Resolução 6 da Conferência de Revisão do Estatuto de Roma, adotada em 11 junho 2010, dispõe:

1. Para os fins deste Estatuto, "crime de agressão" significa o planejamento, a preparação, a iniciação ou a execução, por uma pessoa em uma posição de efetivo controle ou direção sobre as ações políticas ou militares de um Estado, de um ato de agressão que, por sua natureza, gravidade e escala, constitui uma violação manifesta da Carta das Nações Unidas.

2. Para o propósito do parágrafo anterior, "ato de agressão" significa o uso da força armada por um Estado contra a soberania, a integridade territorial ou independência política de outro Estado, ou de qualquer forma incompatível com a Carta das Nações Unidas. Qualquer dos seguintes atos, independentemente de declaração de guerra, constituirá, de acordo com a Resolução da Assembléia Geral das Nações Unidas 3314 (XXIX), de 14 de dezembro de 1974, um ato de agressão...

Como se vê, a definição de "ato de agressão" é a mesma tanto para fins de atribuição de responsabilidade a Estados como a indivíduos. Isso confirma a tese de Bonafè de que "há uma sobreposição completa entre o ato de agressão que implica a responsabilidade agravada do Estado e o crime de agressão que acarreta a responsabilidade penal do indivíduo". 167

O crime de agressão é, portanto, o melhor exemplo de que não há uma dissociação ou uma autonomia completa da responsabilidade penal individual com relação à responsabilidade do Estado. A responsabilidade do indivíduo depende da existência de um ato estatal de

\footnotetext{
${ }^{166}$ CASSESE, Antonio. International Criminal Law. $2^{\mathrm{a}}$ ed. Oxford: Oxford University Press, 2008, p. 155-158.

${ }^{167}$ BONAFÈ, Beatrice I. The Relationship Between State and Individual Responsibility for International Crimes. Leiden: Martinus Nijhoff Publishers, 2009, p. 112.
} 
agressão. Assim, havendo a condenação de um indivíduo por agressão, o Estado também deverá ser punido. Inversamente, se um Estado for responsabilizado por um ato de agressão, os indivíduos envolvidos necessariamente deverão ser processados, ${ }^{168}$ a fim de que seja mantida uma coerência na aplicação do direito internacional. Certamente, isso levará a prolongados debates acerca de qual instituição possui competência para determinar a ocorrência de um ato de agressão. É de se esperar que o Conselho de Segurança reivindique para si essa função, enquanto tribunais como o TPI pelejem para manter sua autonomia e independência frente às determinações do Conselho de Segurança.

Possíveis divergências entre instituições internacionais encarregadas de interpretar e aplicar o direito internacional surgirão, sobretudo considerando o caráter político de tais instituições e a influência ainda muito forte da política no direito internacional - o que é evidente no Conselho de Segurança. Na linha luhmanniana de Marcelo Neves, pode-se dizer que o direito internacional, no que concerne ao crime de agressão, ainda peca por uma corrupção do sistema jurídico pelo sistema político. ${ }^{169} \mathrm{Em}$ outras palavras, o código poder/não poder da política impede a reprodução consistente do código lícito/ilícito do direito internacional. No entanto, a possibilidade de que um tribunal penal internacional independente venha a se pronunciar sobre casos de agressão, a despeito do que resolver o Conselho de Segurança, é seguramente animadora. Essa situação poderá precipitar renovações e desenvolvimentos do direito internacional de forma a torná-lo mais consistente.

A estreita ligação entre os dois regimes de responsabilidade que o crime de agressão apresenta deve servir de alerta para o fato de que o combate à impunidade internacional só será completo se buscar tanto a responsabilidade dos Estados como a dos indivíduos. A mensagem deve ficar clara: o crime de agressão é um só, mas os sujeitos que o cometem podem ser vários (indivíduos e Estados). Se há um só crime, não há falar em crime de agressão perpetrado por um ou mais indivíduos e, concomitantemente, com relação aos mesmos fatos, na ausência de responsabilidade agravada do Estado. Por outro lado, isso não significa não possa haver divergência entre tribunais ou instituições internacionais quanto à caracterização do crime - essa eventual discórdia é, até certo ponto, bem vinda. Contudo, a mesma instituição não deve admitir a ocorrência de agressão para fins de responsabilização de indivíduos ao mesmo tempo em que nega a responsabilidade do Estado.

\footnotetext{
${ }^{168}$ Não se pode afirmar que os indivíduos serão também punidos porque as regras secundárias que regem a responsabilidade penal individual diferem das que regulam a responsabilização de Estados. Assim, um indivíduo dispõe de excludentes de ilicitude e de culpabilidade que não necessariamente coincidem com as excludentes relativas à conduta estatal.

${ }^{169}$ Sobre a corrupção dos sistemas, veja: NEVES, Marcelo. Transconstitucionalismo. São Paulo: WMF Martins Fontes, 2009, p. 42.
} 
Em conclusão, o crime de agressão é o que apresenta a mais íntima relação entre a responsabilidade do Estado e do indivíduo no direito internacional. Há uma sobreposição completa entre o ato de agressão capaz de desencadear as duas formas de responsabilidade. Este crime é, possivelmente, o que mais promete em relação ao desenvolvimento do direito internacional e à proteção dos direitos humanos. Após um longo período em hibernação, desde os julgamentos dos grandes criminosos da $2^{\mathrm{a}}$ Guerra Mundial, há novamente a esperança de que se acabe com a impunidade daqueles que levam seus Estados à guerra, provocando inúmeras mortes e sofrimento e prestando um verdadeiro desserviço à humanidade. ${ }^{170}$

\footnotetext{
${ }^{170}$ A invasão do Iraque, em 2003, pela coalizão liderada pelos Estados Unidos, pode ser citada como um exemplo de agressão que permanece impune. Passados mais de sete anos da invasão e sendo de conhecimento notório o erro dos argumentos apresentados como justificativa da guerra, os principais responsáveis pela agressão gozam de impunidade contínua. O número de vítimas da guerra foi estimado entre 110.000 a mais de 1 milhão de mortos (Associated Press: 110.600 mortes; Opinion Research Business Survey: 1.033 .000 mortes; Lancet Survey: 654.965 mortes; Iraq Family Health Survey: 151.000 mortes).
} 


\section{Conclusão}

Este trabalho abordou o tema da responsabilidade por crimes internacionais a partir de uma perspectiva ainda muito pouco explorada na doutrina jusinternacionalista: a da relação entre a responsabilidade penal individual e a responsabilidade dos Estados por atos internacionalmente ilícitos.

Na primeira parte da monografia foram explicitados os fundamentos dos dois regimes de responsabilidade internacional, tendo em vista o desenvolvimento da disciplina após a $2^{\mathrm{a}}$ Guerra Mundial. Atenção especial foi dedicada aos Artigos da CDI Sobre a Responsabilidade dos Estados por Atos Internacionalmente Ilícitos, que prevêem, além da responsabilidade comum, a forma agravada, por violações graves de normas ius cogens. Embora não haja, de lege lata, uma previsão de responsabilidade penal dos Estados, conceitualmente é perfeitamente plausível a ideia de que Estados podem cometer crimes. ${ }^{171}$ Por outro lado, a responsabilidade penal individual internacional consolidou-se nas últimas duas décadas a partir da criação dos Tribunais ad hoc, de tribunais híbridos e, finalmente, do Tribunal Penal Internacional. Além da existência de diversos crimes internacionais em tratados específicos e estatutos de tribunais, o direito internacional costumeiro reconhece os assim chamados "core crimes" - genocídio, crimes contra a humanidade, crimes de guerra e agressão.

Em seguida, foram apresentadas as teorias que tentam descrever a relação entre os dois regimes de responsabilidade e as implicações dessa relação. Foi ressaltado que os artigos da CDI, bem como o Estatuto de Roma, trataram a questão através de cláusulas de "sem prejuízo", que estabelecem certa independência entre as duas formas de responsabilidade, sem, contudo, definir eventuais interconexões entre elas. No plano doutrinário, Bonafè defendeu a unidade das normas primárias que definem os crimes internacionais, enquanto Cassese afirmou haver dois conjuntos de normas primárias e de normas secundárias, um voltado a indivíduos e outro a Estados. A teoria de Cassese certamente apresenta algumas vantagens, uma vez que admite a comissão de crimes internacionais pensados em termos puramente estatais (ex: agressão) por atores não-estatais, além de implicar uma maior independência dos tribunais penais internacionais, cuja tarefa seria aplicar um direito distinto do interpretado por cortes que julgam Estados. Já a teoria de Bonafè visa a uma aplicação

\footnotetext{
${ }^{171}$ Neste Sentido: PELLET, Alain. Can a State Commit a Crime? Definitely, Yes! European Journal of International Law, Vol. 10, No. 2, 1999, p. 425-434. CANÇADO TRINDADE, Antônio Augusto. Complementarity between State responsibility and individual responsibility for grave violations of human rights: the crime of State revisited. In: RAGAZZI, Maurizio (ed). International Responsibility Today: Essays in Memory of Oscar Schachter. Leiden: Martinus Nijhoff Publishers, 2005, p. 253-269.
} 
mais consistente do direito internacional, realçando o fato de que diversos elementos dos crimes internacionais são determinados de modo semelhante no que toca à atribuição de ambas as formas de responsabilidade.

O terceiro capítulo fez uma breve análise dos elementos dos crimes internacionais (elemento objetivo; elemento subjetivo; excludentes de ilicitude) e da relação entre os dois regimes de responsabilização no âmbito específico de cada espécie dos core crimes do direito internacional. O exame da prática internacional confirmou, em grande parte, a teoria de Bonafè, para quem as normas que descrevem os crimes internacionais são as mesmas para Estados e para indivíduos, havendo uma diferença apenas no nível de normas secundárias, que definem as condições de atribuição de responsabilidade a cada sujeito do direito internacional.

Com efeito, o julgamento da Corte Internacional de Justiça no caso do genocídio na Bósnia confirmou que a Convenção para a Prevenção e Repressão ao Crime de Genocídio, de 1948, se aplica tanto a indivíduos como a Estados. A CIJ também afirmou, expressamente, a dualidade de regimes de responsabilidade no direito internacional. No entanto, a Corte pecou por não explicitar a íntima ligação existente entre as duas formas de responsabilidade, sobretudo no que concerne ao crime de genocídio. Assim, a Corte perpetuou a concepção compartimentalizada da responsabilidade internacional, que só pode levar à "erradicação parcial da impunidade". ${ }^{172}$

Foi constatado que o crime de agressão, com os mais recentes desenvolvimentos do direito internacional, apresenta uma sobreposição completa entre a responsabilidade do Estado e a responsabilidade dos indivíduos, esta última dependendo da verificação de um ato de agressão estatal. Nos crimes contra a humanidade e no genocídio, a sobreposição também é ampla, embora não seja completa pela possibilidade de atores não-estatais perpetrarem esses crimes. Os crimes de guerra apresentam uma exceção à regra, porquanto alguns deles (ex: matar pessoas protegidas; estupro) são interpretados em termos de conduta puramente individual, havendo, então, uma independência entre a responsabilidade do indivíduo e do Estado. Muitos outros, porém, apontam haver uma grande sobreposição entre os dois regimes de responsabilidade, uma vez que dependem da existência de um exército regular ou de um aparelho estatal para sua comissão. O Estatuto de Roma reforçou esse caráter coletivo dos crimes de guerra, provocando uma relação ainda mais próxima entre as duas modalidades de responsabilidade reconhecidas no direito internacional.

\footnotetext{
${ }^{172}$ CANÇADO TRINDADE, Antônio Augusto. Complementarity between State responsibility and individual responsibility for grave violations of human rights: the crime of State revisited. In: RAGAZZI, Maurizio (ed). International Responsibility Today: Essays in Memory of Oscar Schachter. Leiden: Martinus Nijhoff Publishers, 2005, p. 268.
} 
Em conclusão, é importante ressaltar o desenvolvimento ainda precário do tema aqui tratado na prática internacional. A responsabilidade dos Estados continua sendo uma área pouco desenvolvida se comparada à rápida evolução da responsabilidade penal individual no direito internacional. O desenvolvimento do trabalho demonstrou que os vários elementos que compõem os crimes internacionais sugerem uma relação próxima entre a determinação da responsabilidade dos Estados e dos indivíduos. Assim, deve ser pensada e desenvolvida a ideia da determinação concomitante da responsabilidade individual e estatal, visando ao fim da impunidade pelos crimes internacionais e à proteção efetiva dos direito humanos. 


\section{BIBLIOGRAFIA:}

ARENDT, Hannah. Eichmann in Jerusalem. A report on the banality of evil. Nova Iorque: Viking Press, 1963.

BETTATI, Mario. Le crime contre l'humanité. In: HERVÉ, Ascensio; DECAUX, Emmanuel; PELLET, Alain (eds.). Droit International Pénal. Paris: Pedone, 2000.

BONAFÈ, Beatrice I. The Relationship Between State and Individual Responsibility for International Crimes. Leiden: Martinus Nijhoff Publishers, 2009.

CANÇADO TRINDADE, Antônio Augusto. Complementarity between State responsibility and individual responsibility for grave violations of human rights: the crime of State revisited. In: RAGAZZI, Maurizio (ed). International Responsibility Today: Essays in Memory of Oscar Schachter. Leiden: Martinus Nijhoff Publishers, 2005, p. 253-269.

CASSESE, Antonio. International Criminal Law. $2^{\text {a }}$ ed. Oxford: Oxford University Press, 2008.

. The Nicaragua and Tadic Tests Revisited in Light of the ICJ Judgement on Genocide in Bosnia. European Journal of International Law, Vol.18, No.4, 2007.

University Press, 2009.

(ed). The Oxford Companion to International Criminal Justice. Oxford: Oxford

On the Use of Criminal Law Notions in Determining State Responsibility for Genocide. Journal of International Criminal Justice, n. 5, 2007.

CRAWFORD, James. The International Law Commission's Articles on State Responsibility: Introduction, Text and Commentaries. Cambridge: Cambridge University Press, 2002.

; OLLESON, Simon. The Nature and Forms of International Responsibility. In: EVANS, Malcolm D. International Law. $2^{\mathrm{a}}$ ed. Nova Iorque: Oxford University Press, 2006.

EVANS, Malcolm D. International Law. $2^{\text {a }}$ ed. Nova Iorque: Oxford University Press, 2006.

FLETCHER, George P.; OHLIN Jens David. Defending Humanity: when force is justified and why. Nova Iorque: Oxford University Press, 2008.

Reclaiming the Fundamental Principles of Criminal Law in the Darfur Case. Journal of International Criminal Justice, n. 3, 2005.

FRANCK, Thomas. Individual criminal liability and collective civil responsibility: do they reinforce or contradict one another?. Washington University Global Studies Law Review. Vol. 6:567, 2007.

GAJA, Giorgio. Obligations erga omnes, international crimes and jus cogens: a tentative analysis of three related concepts. In: WEILER, Joseph H. H.; CASSESE, Antonio; SPINEDI, Marina (eds.). International Crimes of State: a critical analysis of the ILC's draft article 19 on State responsibility. Berlin, Nova Iorque: de Gruyter, 1988.

GALINDO, George Rodrigo Bandeira. O Crime Compensa? Acerca da viabilidade da noção de crimes internacionais no Direito Internacional. Revista de Informação Legislativa. Brasília, a. 37, No. 147, jul./set. 2000.

JASPERS, Karl. The Question of German Guilt. Trad. E. B. Ashton. Nova Iorque: Fordham University Press, 2000. 
JORGENSEN, Nina H. B. The Responsibility of States for International Crimes. Oxford: Oxford University Press, 2000.

LINTON, Suzannah. New approaches to international justice in Cambodia and East Timor. International Review of the Red Cross, Vol. 84, No. 845, março 2002.

. Cambodia, East Timor and Sierra Leone: Experiments in International Justice.

Criminal Law Forum, No. 12, 2001.

LUHMANN, Niklas. Sociologia do Direito I. Trad. Gustavo Bayer. Rio de Janeiro: Tempo Brasileiro, 1983.

NEVES, Marcelo. Transconstitucionalismo. São Paulo: WMF Martins Fontes, 2009.

NOLLKAEMPER, André. Concurrence between individual responsibility and state responsibility in international law. International and Comparative Law Quarterly. Vol.52, julho 2003.

PELLET, Alain. Can a State Commit a Crime? Definitely, Yes! European Journal of International Law, Vol. 10, No. 2, 1999, p. 425-434.

La responsabilité en droit international: une introduction. [S.I.]: Audiovisual Library of International Law, 2010. Disponível em: http://www.un.org/law/avl/. Acesso em: 18 junho 2010.

QUOC DIN, Nguyen; DAILLIER, Patrick; FORTEAU, Mathias; e PELLET, Alain. Droit International Public. LGDJ. $8^{\mathrm{a}}$ Ed. Paris, 2009.

RAGAZZI, Maurizio (ed). International Responsibility Today: Essays in Memory of Oscar Schachter. Leiden: Martinus Nijhoff Publishers, 2005.

REUTER, Paul. Principes du droit international public. Recueil des Cours de l'Académie de Droit International, tomo 103, 1961.

SCHABAS, William. Genocide in International Law: the Crime of Crimes. Cambridge: Cambridge University Press, 2000.

SCOTT, Craig. Translating torture into transnational tort: conceptual divides in the debate on corporate accountability for human rights harms. In: SCOTT, Craig (ed). Torture as tort: Comparative perspectives on the development of transnational human rights litigation. Oxford: Hart, 2001.

THIAM, Doudou. Third Report on the Draft Code of Crimes Against the Peace and Security of Mankind. YILC, Vol. II(1), 1983.

WALZER, Michael. Just and unjust wars. Nova Iorque: Basic Books, 1977.

WERLE, Gerhard. Principles of International Criminal Law. Haia: Asser Press, 2005. 